\title{
Identification of a specific surface epitope of OmpC for Escherichia coli 0157:H7 with protein topology facilitated affinity mass spectrometry
}

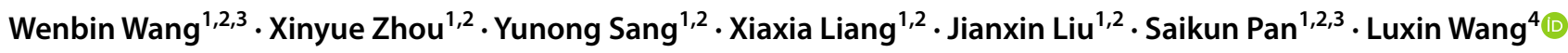

Received: 16 April 2021 / Revised: 4 August 2021 / Accepted: 7 August 2021 / Published online: 25 August 2021

(C) The Author(s) 2021

\begin{abstract}
The goal of this work was to identify the target protein and epitope of a previously reported Escherichia coli O157:H7 (ECO157)-specific monoclonal antibody (mAb) 2G12. mAb 2G12 has shown high specificity for the recovery and detection of ECO157. To achieve this goal, the target protein was first separated by two-dimensional gel electrophoresis (2-DE) and located by Western blot (WB). The protein spots were identified to be the outer membrane protein (Omp) C by matrixassisted laser desorption/ionization time-of-flight mass spectrometry (MALDI-TOF-MS). After that, the target protein was purified by immunoaffinity chromatography (IAC) and subjected to in situ enzymatic cleavage of the vulnerable peptides. Eight eluted peptides of OmpC identified by liquid chromatography-tandem mass spectrometry (LC-MS/MS) were further mapped onto the homologous protein structure of E. coli OmpC (2IXX). The topology of OmpC showed that three peptides had extracellular loops. Epitope mapping with overlapping peptide library and sequence homology analysis revealed that the epitope consisted of a specific peptide, "LGVING," and an adjacent conservative peptide, "TQTYNATRVGSLG.” Both peptides loop around the overall structure of the epitope. To test the availability of the epitope when ECO157 was grown under different osmolarity, $\mathrm{pH}$, and nutrition levels, the binding efficacy of mAb 2G12 with ECO157 grown in these conditions was evaluated. Results further demonstrated the good stability of this epitope under potential stressful environmental conditions. In summary, this study revealed that mAb 2G12 targeted one specific and one conservative extracellular loop (peptide) of the OmpC present on ECO157, and the epitope was stable and accessible on ECO157 cells grown in different environment. Key points

- OmpC is the target of a recently identified ECO157-specific mAb 2 G12.

- Eight peptides were identified from the OmpC by using LC-MS/MS.

- The specificity of mAb 2 G12 is mainly determined by the "LGVING" peptide.
\end{abstract}

Keywords Escherichia coli O157 · Outer membrane protein C · Structure $\cdot$ Identification $\cdot$ Epitope

Wenbin Wang

wenbin66@jou.edu.cn

$\triangle$ Luxin Wang

lxwang@ucdavis.edu

1 Jiangsu Key Laboratory of Marine Bioresources and Environment, Jiangsu Ocean University, Lianyungang, Jiangsu, China

2 Co-Innovation Center of Jiangsu Marine Bio-Industry Technology, Jiangsu Ocean University, Lianyungang, Jiangsu, China

3 Jiangsu Key Laboratory of Marine Biotechnology, Jiangsu Ocean University, Lianyungang, Jiangsu, China

4 Department of Food Science and Technology, University of California Davis, Davis, CA 95618, USA

\section{Introduction}

Immunoassays based on antibody-antigen reactions have been widely used to recover and detect foodborne pathogens, given their high sensitivity, automation, and simplicity (Valderrama et al. 2016). However, the specificity of such assays has been continuously challenged. Taking Escherichia coli O157:H7 (ECO157) as an example, crossreactions of ECO157 monoclonal antibodies with bacterial species such as Escherichia hermannii, Brucella melitensis, and Citrobacter freundii have been reported (Law et al. 2015; Tokarskyy and Marshall 2008). One of the reasons for these cross-reactions is that the target antigen and the epitope of many previously identified antibodies remained largely unknown. Such missing information has limited the 
use of monoclonal antibodies and the development as well as improvement of the specificity of antibody-antigen-based immunoassays. Thus, there is an urgent need for additional studies to identify the target(s) of antibodies on the surface of bacteria.

Several strategies have been reported to study epitopes. Classic structural biology techniques like X-ray crystallography (Malito et al. 2014) have been reported to be the most accurate approaches as they can determine the interacting atoms between the antigen's and antibody's surfaces. However, there is no guarantee of success with these methods, because 1 , only a small fraction of $\mathrm{Ab}-\mathrm{Ag}$ complexes can be crystallized for epitope analysis ( $\mathrm{Lu}$ et al. 2009), and 2, the X-ray crystallography relies on high degrees of sophistication and training (Opuni et al. 2018). Another common biological strategy is to construct an amino acid mutant library of the target protein(s) and translate and express them on yeast or phage (Kowalsky et al. 2015). While these mutagenesis methodologies can be accurate and powerful, local folding defects caused by mutation may affect the results. In addition, another limitation associated with these methods is the technical complexity of library construction and expression, which requires considerable expertise in molecular cloning (Najar et al. 2017). Peptide microarrays have also been used for studying epitopes. These methods rely on reactions between synthetic peptides and antibodies and are user-friendly. However, they are not cost-effective and are more suitable for linear epitope mapping rather than conformational epitopes (Forsström et al. 2014).

In the last three decades, mass spectrometry and enzyme digestion-based methods have been reported to be alternative approaches for rapid and robust epitope mapping (Casina et al. 2014; Lu et al. 2009). The immobilization of antibodies on a solid support for separation (e.g., Sepharose agarose, magnetic beads) and the resistance nature of antibodies to enzymatical proteolysis lay the foundation for the two most frequently used approaches: epitope excision and epitope extraction (Opuni et al. 2018). While epitope extraction is limited to the mapping of linear epitope, epitope excision is applicable to both conformational and linear epitopes (Parker and Tomer 2002). One representative epitope excision method is the affinity-based proteolytic excision, which can be done using lab-made IAC and general LC-MS/MS (Zhao et al. 2014) or MALDI-MS (Moise et al. 2011).

In early 2020, this research team reported a novel $\mathrm{mAb}$ 2G12 with high specificity for ECO157:H7. This antibody showed no cross reaction with 68 non-Escherichia coli 0157 strains when the cell concentrations were at $6 \mathrm{Log}$, and no reaction with $82.35 \%$ of the non-O157 strains when the cell concentrations were at $8 \mathrm{Log}$. The tested non-ECOO157 strains, which did not have cross-reactions with mAb 2G12, included E. coli O121, O111, O103, O45, O26, O101, O86, 078, O60, O25, 09, O6, O2, Shigella Sp., Citrobacter amalonaticus, Enterobacter cloacae, Campylobacter $\mathrm{Sp}$, Aeromonas Sp., Vibrio Sp., Proteus Sp., Listeria monocytogenes, Staphylococcus aureus, and Bacillus subtilis. Initial evaluations indicated that the target of this $\mathrm{mAb}$ could be an outer member protein (Omp) with a size of approximately $35 \mathrm{kDa}$ (Wang et al. 2021).

Antibodies against the bacterial Omps recognize the extracellular part of the transmembrane protein (Hollingshead et al. 2018; Malito et al. 2014). Information about the structure and topology of Omps could reveal the location of extracellular peptides, the lipid bilayer, and the periplasm (Dobson et al. 2015). This information would be instructive for subsequent epitope mapping. Over the years, several structures and topologies have been identified from bacterial Omps, and many of them have a $\beta$-barrel architecture with short loops between strands on the periplasmic side and large extended loops on the extracellular side (Rollauer et al. 2015). With the increasing amount of protein structure available in the protein data bank (PDB) and the topology information available in the Orientations of Proteins in Membranes (OPM) database (Lomize et al. 2012), the structure and topology of Omps are now available for the identification of unknown epitopes (Gourlay et al. 2017).

The goal of this paper was to systematically investigate the target antigen and epitopes of this ECO157-specific mAb 2G12 and evaluate its availability and affinity with ECO157 under various simulated environmental stresses, e.g., osmolarity, $\mathrm{pH}$, and nutrition levels. Figure 1 illustrates the key steps followed in this study. Two-DE, WB, and MALDI-TOF-MS were used for the separation, locating, and identification of the target Omp. IAC and in situ trypsin digestion were used for the purification of the target protein and the releasing of untargeted peptides. Eluted peptides of OmpC identified by LC-MS/MS were then mapped onto the protein structure of E. coli OmpC. Peptide libraries of the extracellular peptides and indirect enzyme-linked immunosorbent assay (ELISA) were used for epitope mapping. The sequence homology of the target OmpC extracellular peptides with large numbers of non-O157 strains and homologous OmpC structures were analyzed via the Basic Local Alignment Search Tool (BLAST) for the confirmation of the mAb 2G12 specificity.

\section{Materials and methods}

\section{Main reagents and instruments}

Iodoacetamide (IAA), dithiothreitol (DTT), goat anti-mouse IgG, trypsin, trifluoroacetic acid, 3-[(3-Cholamidopropyl) dimethylammonio]-1-propanesulfonate hydrate (CHAPS), NeutrAvidin protein, acetonitrile (ACN), trifluoroacetic acid (TFA), methanol, N,N-dimethylformamide (DMF), gelatin, ProClin 
2DE of ECO157

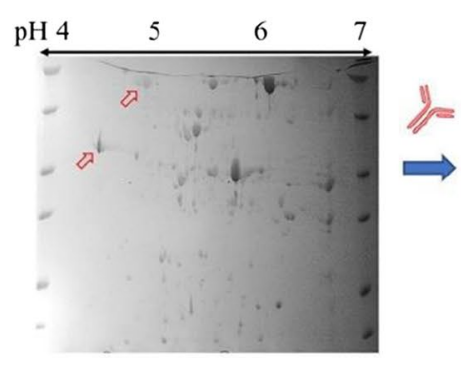

Sequence specificity
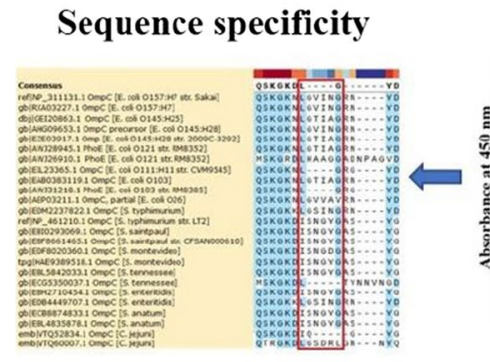



Epitope mapping

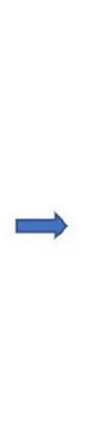

MALDI-TOF/TOF

IAC
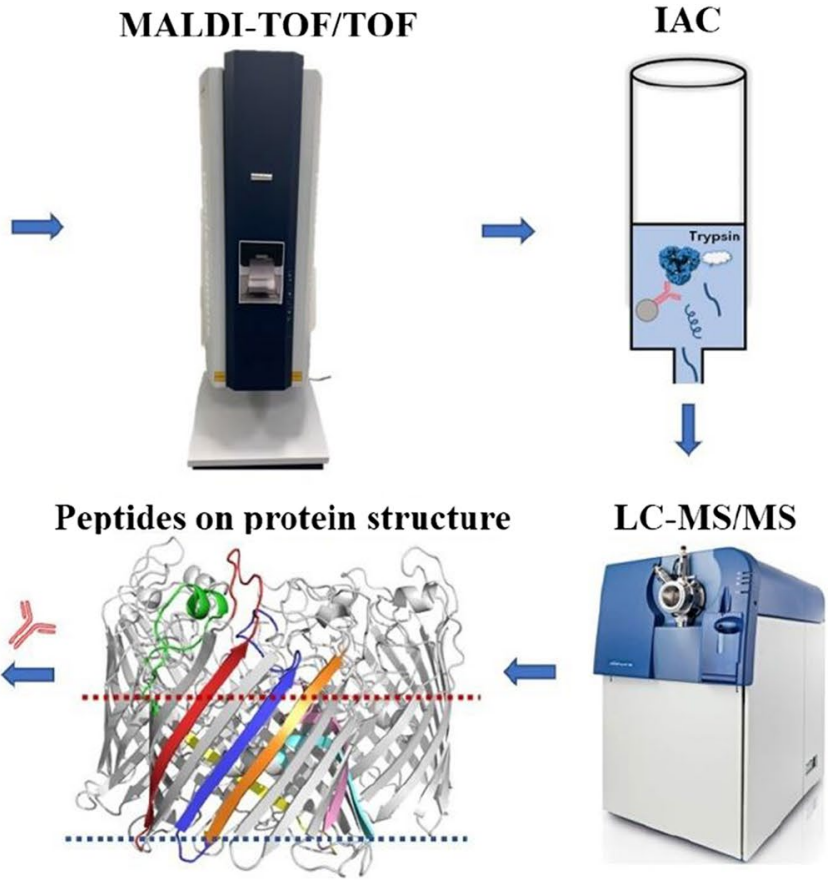

Fig. 1 The workflow of the identification of ECO157-specific epitopes. Key steps include 2-dimensional electrophoresis (2-DE), matrix-assisted laser desorption/ionization time-of-flight/time-offlight (MALDI-TOF/TOF), in situ enzymatic hydrolysis in immunoaf-

300, 3,3',5,5'-tetramethylbenzidine (TMB), and sulfuric acid were purchased from Sigma-Aldrich (St. Louis, MO, USA). Pharmalyte 4-6.5 (high-resolution amphoteric electrolyte) for isoelectric focusing (IEF), immobilized $\mathrm{pH}$ gradient (IPG) strips ( $\mathrm{pH} 4-7$ ), IPG buffer $\mathrm{pH} 4-7$, mineral oil, 2-D clean-up kit protein purification kit, 2-D quant-kit protein quantitative kit, polyvinylidene difluoride (PVDF) membrane, Ettan ${ }^{\mathrm{TM}}$ IPGphor 3 solid-phase $\mathrm{pH}$ ladder, degree isoelectric focusing instrument, $\operatorname{Ettan}^{\mathrm{TM}}$ DALTsix vertical electrophoresis instrument, and TE 70 semi-dry transfer system were from GE Healthcare (Chicago, IL, USA). ABI 5800 MALDI-TOF/TOF Plus mass spectrometer was from Applied Biosystems (Foster City, CA, USA). Gel imager was from Bio-Rad ChemiDoc (Hercules, CA, USA). Multi-Mode Reader Cytation5 was from Biotek (Winooski, VT, USA). Skim milk was purchased from BD (Lake Franklin, NJ, USA). Goat anti-mouse IgG was obtained from Jackson ImmunoResearch Inc. (West Grove, PA, USA). TMB substrate for Western blot was provided by GBCBIO Technologies Inc. (Guangzhou, China). High binding 96-well plates were purchased from Greiner Bio-one (Frickenhausen, Germany). $\mathrm{NaHCO}_{3}$, $\mathrm{NaCl}$, Tris-Base, $\mathrm{NH}_{4} \mathrm{HCO}_{3}, \mathrm{Na}_{2} \mathrm{CO}_{3}$, Tween 20, and acetic acid were obtained from Sinopharm Chemical Reagent Co., Ltd. (Shanghai, China). finity chromatography (IAC), liquid chromatography-tandem mass spectrometry (LC-MS), protein structure, membrane protein topology, sequence homology, and epitope mapping

\section{Preparation of protein samples}

Three Escherichia coli O157:H7 strains (CICC 21,530, ATCC 35,150, and ATCC 700,728) were obtained from the China Center of Industrial Culture Collection (CICC) and American Type Culture Collection (ATCC). Cultures were activated in Luria-Bertani (LB) broth for overnight at $37{ }^{\circ} \mathrm{C}$. After centrifugation at $5,000 \mathrm{~g}$ and $4{ }^{\circ} \mathrm{C}$ for $10 \mathrm{~min}$, cells recovered from $100 \mathrm{~mL}$ of liquid culture were resuspended in $10 \mathrm{~mL}$ of fresh bacteria cell lysis buffer (8 M urea, $4 \%$ chaps, $2 \%$ IPG buffer, $40 \mathrm{mM}$ DTT). Whole protein extract was prepared by an ultrasonic crusher (LCCS950, Tocan, Shanghai, China). Briefly, the sample was ultrasonicated at $4{ }^{\circ} \mathrm{C}$ in an ice bath at $475 \mathrm{~W}$ for $20 \mathrm{~min}$ with a 9.9-s interval after every $5 \mathrm{~s}$ of sonication. The supernatant was collected after centrifugation at $12,000 \mathrm{~g}$ and $4{ }^{\circ} \mathrm{C}$ for $10 \mathrm{~min}$. To purify the protein, trichloroacetic acid (TCA)-acetone (10\%) pre-cooled at $-20{ }^{\circ} \mathrm{C}(40 \mathrm{~mL})$ was added with a volume ratio of 5:1 to precipitate the protein overnight at $-20{ }^{\circ} \mathrm{C}$. The precipitation was collected by centrifugation at $12,000 \mathrm{~g}$ and $4{ }^{\circ} \mathrm{C}$ for $10 \mathrm{~min}$. After that, $20 \mathrm{~mL}$ of pre-cooled acetone was added and mixed. The precipitation was collected again by centrifugation at $12,000 \mathrm{~g}$ and $4{ }^{\circ} \mathrm{C}$ for $15 \mathrm{~min}$, and this protein precipitation process was repeated twice. After air-drying at $25^{\circ} \mathrm{C}$, the precipitation was added with $5 \mathrm{~mL}$ of sample lysate and 
incubated in a water bath at $30{ }^{\circ} \mathrm{C}$ for $1 \mathrm{~h}$ to fully dissolve the protein. After centrifugation at 12,000 g for $10 \mathrm{~min}$, the supernatant was collected and centrifuged again to fully remove incompatible impurities. The supernatant sample of ECO157 CICC 21,530 was further purified and quantified by a $2 \mathrm{D}$ clean-up kit and a $2 \mathrm{D}$ quant-kit according to the instructions of the manufacturer (GE Healthcare). The supernatant sample of ECO157 ATCC 700,728 was prepared the same way and dialyzed with $10 \mathrm{mM}$ of PBS for $24 \mathrm{~h}$. After centrifugation at 12,000 g for $10 \mathrm{~min}$, the supernatant was collected and quantified by the Bradford assay (Compton and Jones 1985) before being used for IAC. The cell lysate of ECO157 ATCC 35,150 was analyzed by gel electrophoresis (SDS-PAGE) and Western blot. The SDS-PAGE gel was aligned with the Western blot and the target protein band (stained by Coomassie blue) was cut, decolorized, and subjected to in-gel digestion and the following analysis by the LC-MS/MS.

\section{Two-dimensional gel electrophoresis}

Two-dimensional gel electrophoresis (2-DE) was conducted following the protocol in the General Electric (GE) manual. One hundred seventy microliters $(2.5 \mathrm{mg})$ of ECO157 protein was mixed with an equal volume of hydration solution ( $8 \mathrm{M}$ urea, 2\% CHAPS, $0.5 \%$ IPG buffer, $0.002 \%$ bromophenol blue), and then added into the isoelectric focusing hydration tank (GE Healthcare, $18 \mathrm{~cm}$ ). The IPG strip (PH 4-7 L, $18 \mathrm{~cm}$ ) was then immersed in the sample buffer and covered with mineral oil $(2.3 \mathrm{~mL})$. IEF was performed according to the following steps: (1) Stp (one step voltage rise) $30 \mathrm{~V} 12 \mathrm{~h}$, (2) Stp $200 \mathrm{~V} 1 \mathrm{~h}$, (3) Stp $500 \mathrm{~V} 1 \mathrm{~h}$, (4) Grd $1000 \mathrm{~V}$ $1 \mathrm{~h}$, (5) Grd (gradient voltage rise) $4000 \mathrm{~V} 1 \mathrm{~h}$, (6) Grd 8000 V 1 h, (7) Stp 8000 V 100,000 Vhr. The IPG strip was then taken to a tank and incubated with the equilibrium solution (6 M urea, 30\% glycerol, 2\% SDS, $0.002 \%$ bromophenol blue, $75 \mathrm{mM}$ Tris- $\mathrm{HCl}, \mathrm{pH}$ 8.8) containing $2 \%$ ( $\mathrm{m} / \mathrm{v})$ DTT $(10 \mathrm{~mL})$ for $15 \mathrm{~min}$. After that, it was added with the equilibrium solution containing $3 \%(\mathrm{~m} / \mathrm{v})$ IAA $(10 \mathrm{~mL})$ and incubated for an additional $15 \mathrm{~min}$. The $10 \%$ separating SDS-PAGE gel $(18 \mathrm{~cm} 16 \mathrm{~cm} 1.5 \mathrm{~mm})$ was prepared following instructions of the manufacturer (GE Healthcare). Vertical electrophoresis was conducted in two steps: step 1: $600 \mathrm{~V}, 400 \mathrm{~mA}, 2 \mathrm{~W} / \mathrm{gel}$, and step 2: $600 \mathrm{~V}, 400 \mathrm{~mA}, 20 \mathrm{~W} / \mathrm{gel}$. After electrophoresis, the gel was added with $60 \mathrm{~mL}$ of $12.5 \%$ trichloroacetic acid and incubated for $30 \mathrm{~min}$. The gel was stained with $60 \mathrm{~mL}$ of $0.1 \%$ Coomassie brilliant blue G-250 for $10 \mathrm{~min}$. Then, the gel was added with $60 \mathrm{~mL}$ of $1 \%$ acetic acid with $1 \%$ methanol. The buffer was replaced every $3-5 \mathrm{~h}$ until the background of the gel was completely detained.

\section{Western blot}

WB was conducted following the protocols described by Wang et al. (2020). To better fit the TE 70 semi-dry transfer system $(14 \mathrm{~cm} 16 \mathrm{~cm})$, the $2-D E$ gel $(18 \mathrm{~cm} 16 \mathrm{~cm})$ was cut into four parts $(9 \mathrm{~cm} 9 \mathrm{~cm} 1.5 \mathrm{~mm} 2$, two $9 \mathrm{~cm} 7 \mathrm{~cm} 1.5 \mathrm{~mm} 2)$ and transferred onto PVDF membrane $(9 \mathrm{~cm} 9 \mathrm{~cm} 1.5 \mathrm{~mm} 2$, two $9 \mathrm{~cm} 7 \mathrm{~cm} 1.5 \mathrm{~mm} 2$ ) individually. Each gel was placed on the PVDF membrane (immersed in $10 \mathrm{~mL}$ of methanol for $15 \mathrm{~s}$ before use) that was supported with two layers of filter paper pre-immersed in the anode buffer I $(300 \mathrm{mM}$ Tris-HCl, 10\% methanol, $\mathrm{pH} 10.4$ ) and one layer of filter paper pre-immersed in anode buffer II ( $25 \mathrm{mM}$ Tris-HCl, $10 \%$ methanol, $\mathrm{pH} 10.4)$. Another three layers of filter paper pre-immersed in cathode buffer $(25 \mathrm{mM}$ Tris- $\mathrm{HCl}, 40 \mathrm{mM}$ glycine, $10 \%$ methanol, $\mathrm{pH}$ 9.4) were then attached to the top of the gel. The layers were then put in the semi-dry transfer system and the protein was transferred at $25 \mathrm{~mA}$ for $30 \mathrm{~min}$. The PVDF membrane was then immersed in $10 \mathrm{~mL}$ of methanol for $10 \mathrm{~s}$ and blocked with $30 \mathrm{~mL}$ of $5 \%$ skim milk in $10 \mathrm{mM}$ of PBS (pH 7.2) at $4{ }^{\circ} \mathrm{C}$ overnight. Between each WB step, membranes were washed four times in $15 \mathrm{~mL}$ of $10 \mathrm{mM}$ phosphate-buffered saline with tween 20 (PBST) for $3 \mathrm{~min}$ of gentle shaking. Fifteen microliters of the antibody $2 \mathrm{G} 12(0.3 \mu \mathrm{g} / \mathrm{mL})$ in PBST was added and incubated with the PVDF membrane at $25{ }^{\circ} \mathrm{C}$ for $1 \mathrm{~h}$. The preparation and detailed message of mAb 2G12 was described in our previous work (Wang et al. 2021). Fifteen microliters of the goat anti-mouse $\mathrm{IgG}$ antibody $(0.2 \mu \mathrm{g} / \mathrm{mL})$ in PBST was added and allowed to react at $25{ }^{\circ} \mathrm{C}$ for $1 \mathrm{~h}$. After four times of washing as described above, $10 \mathrm{~mL}$ of the commercial TMB substrate for Western blot (GBCBIO, Guangzhou, China) was added and allowed to react for $5 \mathrm{~min}$ at $25^{\circ} \mathrm{C}$. The reaction was stopped by replacing the substrate in $15 \mathrm{~mL}$ of double-distilled water for $20 \mathrm{~s}$, and pictures were captured with a gel imager (Bio-Rad ChemiDoc, Hercules, CA, USA).

\section{In-gel digestion and MALDI-TOF/TOF}

After WB, target gel spots on the Coomassie blue-stained 2-DE and SDS-PAGE were taken and digested by trypsin as described by Katayama et al. (2001). Briefly, gel spots were transferred into $0.5-\mathrm{ml}$ centrifuge tubes and rinsed twice with $300 \mu \mathrm{L}$ of ultrapure water. Three hundred microliters of $25 \mathrm{mM}$ of $\mathrm{NH}_{4} \mathrm{HCO}_{3}$ in $50 \%(\mathrm{~V} / \mathrm{V}) \mathrm{ACN}$ was added to decolorize the gel dots for $30 \mathrm{~min}$. The gel dots were then rinsed with $300 \mu \mathrm{L}$ of double-distilled water two times. The double-distilled water was aspirated and added with 300 $\mu \mathrm{L}$ of $50 \%(\mathrm{~V} / \mathrm{V}) \mathrm{ACN}$ to dehydrate for $30 \mathrm{~min}$. The buffer was replaced with $300 \mu \mathrm{L}$ of $100 \%(\mathrm{~V} / \mathrm{V}) \mathrm{ACN}$ and the gel dots were dehydrated for another $30 \mathrm{~min}$. The buffer was replaced with $10 \mu \mathrm{L}$ of $25 \mathrm{mM} \mathrm{NH}_{4} \mathrm{HCO}_{3}$ and dots were allowed to swell for $30 \mathrm{~min}$. Trypsin $(0.4 \mu \mathrm{g})$ in $200 \mu \mathrm{L}$ of 
$25 \mathrm{mM} \mathrm{NH}_{4} \mathrm{HCO}_{3}$ was then added and incubated in a water bath at $37{ }^{\circ} \mathrm{C}$ for overnight. The supernatant was transferred into new 0.5 -ml centrifuge tubes, and the remaining gel was added with $50 \mu \mathrm{L}$ of $5 \%$ TFA in $67 \% \mathrm{ACN}$ and incubated at $37{ }^{\circ} \mathrm{C}$ for 30 min to extract the remaining peptides. After centrifugation at 5,000 g for $5 \mathrm{~min}$, the peptide extracts and the supernatant of gel spots were combined and air-dried at $37^{\circ} \mathrm{C}$. A gel particle with the comparable size of the protein spots was cut from the unstained part of the gel and used as the negative control.

For MALDI-TOF/TOF analysis, two samples and the control were resuspended with $5 \mu \mathrm{L}$ of $0.1 \% \mathrm{TFA}$ followed by mixing in $1: 1$ ratio with a matrix consisting of a saturated solution of $\alpha$-cyano-4-hydroxy-trans-cinnamic acid in 50\% ACN with $0.1 \%$ TFA. One microliter of the mixture was then spotted on a stainless-steel sample plate. Three replicates were done for each sample. Peptide MS and MS/MS were performed on an ABI 5800 MALDI-TOF/TOF Plus mass spectrometer and the data was acquired in a positive MS reflector using a CalMix 5 standard to calibrate the instrument (ABI5800 Calibration Mixture). Both the MS and the MS/MS data were integrated and processed by using the GPS Explorer V3.6 software (Applied Biosystems, USA) with default settings. Based on the combined MS and MS/ MS spectra, proteins were successfully identified based on a $95 \%$ or higher confidence interval of their scores in the MASCOT V2.3 search engine (Matrix Science Ltd., London, UK). The following search parameters were used: $E$. coli $\mathrm{O} 157$ as target strain; trypsin as the digestion enzyme; one missed cleavage site; fixed modifications of carbamidomethyl (C); partial modifications of acetyl (protein N-term), deamidated (NQ), oxidation (M); $100 \mathrm{ppm}$ for precursor ion tolerance and 0.4 Da for fragment ion tolerance. Two trials of the experiments were conducted and three replicates of each sample were tested for protein identification in each trial.

\section{Affinity chromatography and LC-MS/MS}

The affinity chromatography column was prepared as described by Graeber and Korkhov (2020). Three hundred milligrams of cyanogen bromide $(\mathrm{CNBr})$ Sepharose agarose was swelled with $3 \mathrm{~mL}$ of $1 \mathrm{mM} \mathrm{HCl}$ solution for $15 \mathrm{~min}$ and washed with coupling buffer $\left(0.1 \mathrm{M} \mathrm{NaHCO}_{3}, 0.5 \mathrm{M}\right.$ $\mathrm{NaCl}, \mathrm{pH}$ 9.0). After centrifugation at $1,500 \mathrm{~g}$ for $2 \mathrm{~min}$, the supernatant was discarded, and $2 \mathrm{~mL}$ of E. coli O157: $\mathrm{H} 7 \mathrm{mAb} 2 \mathrm{G} 12(1 \mathrm{mg} / \mathrm{mL})$ in coupling buffer was added to resuspend the Sepharose. Samples were then rotated at $25{ }^{\circ} \mathrm{C}$ for $2-4 \mathrm{~h}$. An $\mathrm{OD}_{280}$ value of the supernatant at less than $1 / 10$ of the original $\mathrm{OD}_{280}$ value indicated the endpoint of coupling. After three repeated washing processes with $3 \mathrm{~mL}$ of coupling buffer and centrifugation at 1,500 $\mathrm{g}$ for $2 \mathrm{~min}$, the supernatant was discarded and $2 \mathrm{~mL}$ of blocking solution (1 M Tris-Base in coupling buffer) was added and incubated with shaking at $25{ }^{\circ} \mathrm{C}$ for $2 \mathrm{~h}$. After centrifugation, the agarose was retained and resuspended in $2 \mathrm{~mL}$ of coupling buffer. After that, $0.9 \mathrm{~mL}$ of agarose solution was added to the vertically placed column, and was let to stand still for 10 min to fully sink the agarose to the bottom. An upper sieve plate was installed, and the column was washed with $10 \mathrm{~mL}$ of $10 \mathrm{mM}$ PBS. Finally, the columns were added with $1 \mathrm{~mL}$ of $10 \mathrm{mM}$ PBS with $0.01 \%$ ProClin 300 (preservative) and stored at $4{ }^{\circ} \mathrm{C}$ before use. Based on the amount of $\mathrm{Ab}$ used for two columns $(2.0 \mathrm{mg})$, the conjunction rate of $\mathrm{Ab}$ to the Sepharose (90\%), and the volume of agarose solution for one column $(0.9 \mathrm{~mL})$, it is estimated that there was approximately $0.8 \mathrm{mg}$ of mAb $2 \mathrm{G} 12$ in each column.

In situ enzymatic hydrolysis in IAC was used to capture the target protein and purify the epitope (Iuraşcu et al. 2016). The two columns prepared above were washed with $20 \mathrm{~mL}$ of $10 \mathrm{mM}$ PBS before loading the samples. Fifty milliliters of the prepared E. coli O157: H7 ATCC 700,728 protein sample $(0.5 \mathrm{mg} / \mathrm{mL}$ in PBS) was slowly loaded to the columns $(10 \mathrm{~mL}$ per column $)$ at $30{ }^{\circ} \mathrm{C}$ and passed through the columns by gravity. After washing with PBST, $260 \mu \mathrm{g}$ (Group A) and $520 \mu \mathrm{g}$ (Group B) of trypsin in $2 \mathrm{~mL}$ of $25 \mathrm{mM} \mathrm{NH}_{4} \mathrm{HCO}_{3}$ were added respectively to the substrate of the two columns (bottom sealed) and incubated at $37{ }^{\circ} \mathrm{C}$ for $30 \mathrm{~min}$. The columns were then washed with PBST again to rinse the free peptides. Bounded peptides were eluted with $2 \mathrm{~mL}$ of $0.1 \%$ TFA, $2 \mathrm{M}$ acetic acid, and pure methanol. Elutes from the same column were collected and combined as one sample.

Eluted samples were then centrifuged at $12,000 \times g$ for $10 \mathrm{~min}$, and the supernatant was dried by the centrifugal concentrator and kept frozen at $-20{ }^{\circ} \mathrm{C}$ before the test. MS analysis was performed using the SCIEX's TripleTOF 5600 LC/MS system. Peptide samples were dissolved in $5 \mu \mathrm{L}$ of $0.1 \%$ formic acid and added into the $\mathrm{C} 18$ column $(5 \mu \mathrm{m}$, $5 \times 0.3 \mathrm{~mm})$ by autosampler and then eluted to the analytical column $(75 \mu \mathrm{m} \times 150 \mathrm{~mm}, 3 \mu \mathrm{m}$ particle size, $100 \AA$ pore size, Eksigent). Two mobile phases (mobile phase $\mathrm{A}: \mathrm{H}_{2} \mathrm{O}$, $0.1 \%$ formic acid and mobile phase $\mathrm{B}$ : $\mathrm{ACN}, 0.1 \%$ formic acid) were used to establish a 30 -min gradient $(0 \mathrm{~min}$ in $5 \% \mathrm{~B}, 15 \mathrm{~min}$ of $5-35 \% \mathrm{~B}, 1 \mathrm{~min}$ of $35-80 \% \mathrm{~B}, 80 \% \mathrm{~B}$ for $5 \mathrm{~min}, 0.1 \mathrm{~min}$ of $80-5 \% \mathrm{~B}, 5 \% \mathrm{~B}$ for $8.9 \mathrm{~min}$ ). The flow rate of the liquid phase was $300 \mathrm{~nL} / \mathrm{min}$. In the mass spectrometer information-dependent acquisition (IDA) mode, each scan cycle contained an MS full scan ( $\mathrm{m} / \mathrm{z}$ range is $350-1500$, ion accumulation time $250 \mathrm{~ms}$ ), followed by 40 MS/MS scans ( $\mathrm{m} / \mathrm{z}$ range is $100-1500$, ion accumulation time $50 \mathrm{~ms}$ ). The MS/MS data was acquired when the precursor ion signal was greater than $120 \mathrm{cps}$ and the charge number was $+2 \sim+5$. The exclusion time for repeated ion collection was $18 \mathrm{~s}$. The mass spectrometry data generated by TripleTOF 5600 was retrieved by ProteinPilot (V4.5), and 
the database search algorithm was Paragon. The database used for searching was the proteome reference database of E. coli $\mathrm{O} 157: \mathrm{H} 7$ in UniProt. Two trials of the experiments were conducted with three replicates of each sample tested for $\mathrm{LC}-\mathrm{MS} / \mathrm{MS}$ in this trial.

\section{Protein structure, topology analysis}

The protein structures and sequences of E. coli OmpC (2IXX, 2J1N) and Salmonella Typhimurium (3UPG) were obtained from the PDB. The topology information of OmpC (2IXX) was also available in the OPM database. The OmpC structure was analyzed by PyMOL, and the eluted peptides of OmpC after IAC and LC-MS/MS were labeled with different colors on the structure of E. coli OmpC (2IXX), which has high homology (query cover $94 \%$, percent identity 92.37\%) with the OmpC of ECO157. After comparison of the topology of OmpC on the cell membrane and locations of the eluted peptides on OmpC, peptides located on the extracellular loops were chosen for further analysis of the epitope.

\section{Epitope mapping and sequence homology analysis}

The peptides of loop1 (TQTYNATRVGSLG), loop2 (QSKGKNLGVINGRNYD), and loop3 (YKINLLDDNQFTRD) and overlapping peptide library of loop2, which consists of six peptides with peptide length at 6 and offset at 2, were synthesized and purified by HPLC (>90\%) to further study the exact epitopes of mAb 2G12. The detailed peptide library of loop2 was synthesized because it has a much higher precursor signal (1269.363) in LC-MS/MS and is more accessible on the OmpC structure than other OmpC peptides. Loops 1, 2, and 3 were named according to the clockwise manner of the three adjacent long peptides with extracellular loops. All peptides were modified with a spacer arm of -SGSG- and a recognition molecule of biotin at the $\mathrm{N}$ terminal. The protocol of epitope mapping was conducted by indirect ELISA as described by Heuzenroeder et al. (Heuzenroeder et al. 2009) with minor revision. Briefly, the peptides were completely dissolved with a proper solvent like $\mathrm{H}_{2} \mathrm{O}$ (Pep2, Pep2.3, Pep2.6), 10 mM PBS (Pep3, Pep2.1, Pep2.2, Pep2.4) and DMF (Pep1, Pep2.5) and stored at $-80^{\circ} \mathrm{C}$. Each well of the 96-well plate was filled with $50 \mu \mathrm{L}$ of NeutrAvidin protein $\left(3 \mu \mathrm{g} / \mathrm{mL}\right.$ in $10 \mathrm{mM}$ PBS ) and kept at $37^{\circ} \mathrm{C}$ for $2 \mathrm{~h}$. The plates were washed 3 times with $10 \mathrm{mM}$ of PBST $(100 \mu \mathrm{L} /$ well). This washing process was also conducted between each step of the ELISA protocol. One hundred microliters of $0.2 \%$ gelatin in $10 \mathrm{mM}$ carbonate-bicarbonate buffer was then added to each well to block the non-specific reactions overnight at $4{ }^{\circ} \mathrm{C}$. After blocking, peptides were diluted to $500 \mu \mathrm{g} / \mathrm{mL}$ with PBST and added to each well
(50 $\mu \mathrm{L} /$ well), and incubated at $4{ }^{\circ} \mathrm{C}$ overnight. Fifty microliters of $\mathrm{mAb} 2 \mathrm{G} 12(3 \mu \mathrm{g} / \mathrm{mL})$ in PBST was added to each well of the plate and incubated at $25{ }^{\circ} \mathrm{C}$ for $1 \mathrm{~h}$ on an orbit shaker. Each well was added with goat anti-mouse IgG $(0.7 \mu \mathrm{g} / \mathrm{mL}, 50 \mu \mathrm{L} /$ well $)$, covered by a lid, and incubated at $25{ }^{\circ} \mathrm{C}$ for another hour. TMB substrate $(50 \mu \mathrm{L} /$ well $)$ was added to the plate and incubated at $37^{\circ} \mathrm{C}$ for $15 \mathrm{~min}$. Twenty-five microliters of $2 \mathrm{M}$ of sulfuric acid was added into each well before reading the absorbance at $450 \mathrm{~nm}$ with the Multi-Mode Reader Cytation5 (Biotek, Winooski, VT, USA).

The sequence homology of the three extracellular loops was studied by BLASTp in NCBI. The query sequence (QEQ39178.1) was the OmpC of ECO157 and the subjected organisms were the tested strains including different $E$. coli serotypes that showed no cross-reaction with $\mathrm{mAb}$ $2 \mathrm{G} 12$. The homology of the three extracellular loops with all non-O157 strains was also studied in the same way. The parameter of the database was all the non-redundant protein sequences. For all non-O157 strains, the OmpC sequences matched a strain name at the species level were analyzed. The results of multi alignment were saved as aln files and visualized by SnapGene Viewer (V4.2.11).

\section{The availability of epitopes for $\mathrm{mAb} 2 \mathrm{G} 12$ under different growth conditions}

ECO157 grew under different osmotic pressure, low nutrition, and $\mathrm{pH}$ levels were prepared for testing the availability of the epitope with $\mathrm{mAb} 2 \mathrm{G} 12(4 \mathrm{mg} / \mathrm{mL})$ (Desai and Kenney 2019; Hahm and Bhunia 2006). ECO157 (LJH643, a clinical isolate obtained from a cantaloupe outbreak was kindly provided by Dr. Linda J. Harris at UC Davis) was first activated on LB agar. The single colony was inoculated to buffered peptone water (BPW) and cultured at $37^{\circ} \mathrm{C}$ for $12 \mathrm{~h}$. This freshly prepared culture was then added into fresh buffered peptone water (BPW) with different salt concentrations $(1,2$, or $4 \%$ ) or $\mathrm{pH}$ values ( $\mathrm{pH}$ of 7.2 or 4.3 adjusted by $\mathrm{HCl})$ with a ratio of $1 \%(\mathrm{v} / \mathrm{v})$. To mimic a condition with limit nutrient, $0.1 \%(\mathrm{~m} / \mathrm{v})$ peptone water was used. The inoculated broth was incubated at $37{ }^{\circ} \mathrm{C}$ for $24 \mathrm{~h}$. One hundred fifty microliters of the inoculated medium in each group was added in a microplate with three replicates and the growth curves were automatically collected by measuring the OD $600 \mathrm{~nm}$ in Cytation 5 for $23 \mathrm{~h}$. The concentrations of the culture were also obtained by plating onto plate count agar. The cells were collected by centrifugation at $5,000 \mathrm{~g}$ and $4{ }^{\circ} \mathrm{C}$ for $10 \mathrm{~min}$, and resuspended in $10 \mathrm{mM}$ of PBS. The binding between mAb 2G12 and ECO157 was measured by indirect ELISA with the same coating concentration of ECO157 at $7.0 \log _{10} \mathrm{CFU} / \mathrm{mL}$. All the results were obtained with three replicates in each group. 


\section{Results}

\section{Identification of the target protein of $\mathrm{mAb} 2 \mathrm{G} 12$}

Figure 2A shows the 2D image of the protein purified from the cell lysates of ECO157 (CICC 21,530). The protein dots were well separated according to molecular weight (MW) and isoelectric point (PI). The Western blot results of the four divided parts of two-dimensional gel electrophoresis (2-DE) showed that mAb $2 \mathrm{G} 12$ reacted with two protein spots, with the sizes being approximately $35 \mathrm{kDa}(\mathrm{pI}$ at around 4.5) and $70 \mathrm{kDa}$ (with $\mathrm{pI}$ at around 5.0) on the left-upper part (Fig. 2B). The other three parts resulted in no protein spot and were not imaged. The results of in-gel digestion and MALDI-TOF/TOF mass spectrometry showed that the approximately $35 \mathrm{kDa}$ protein dot was identified to be OmpC (40.48 kDa, pI 4.5), and the approximately $70 \mathrm{kDa}$ protein dot was pinpointed as chaperone DnaK (69 kDa, pI 4.8) (Supplemental Figure S1).

\section{Peptides revealed by IAC, LC-MS/MS, and protein structure analysis}

IAC column prepared with mAb $2 \mathrm{G} 12$ was used to purify OmpC from the whole proteins of ECO157 lysates and the target peptides after in situ enzymatic hydrolyses. Two groups with different amounts of trypsin were optimized for protein hydrolysis in the column. The trypsin $(24 \mathrm{kDa})$ of $260 \mu \mathrm{g}$ (group A) and $520 \mu \mathrm{g}$ (group B) was chosen to mimic the theoretical molecular ratio of trypsin to OmpC $(40.48 \mathrm{kDa})$ at $1: 1$ and 2:1. The amount of OmpC was calculated based on the conjugated amount of $\mathrm{mAb}$ in each column ( $0.8 \mathrm{mg} /$ column $)$ at the optimal condition when one antibody bound with two OmpC ( $0.43 \mathrm{mg} /$ column). As shown in Table 1, group A with $260 \mu \mathrm{g}$ of trypsin added resulted in 24 peptides ( 24 spectra) detected from a major outer membrane lipoprotein $(8.3 \mathrm{kDa})$ with a protein score of 37.48 , and 13 peptides (14 spectra) detected from OmpC with a protein score of 27.46. The protein score ranked second among all identified proteins. Group B with $520 \mu \mathrm{g}$ of trypsin added resulted in eight peptides (nine spectra) detected from $\mathrm{OmpC}$ with a protein score of 17.58, which ranked first among identified proteins. The major outer membrane lipoprotein (protein score 16.14) ranked second and has eight peptides (eight spectra). The detailed sequences and information of the eluted OmpC peptides in groups $\mathrm{A}$ and B are provided in Supplemental Tables S1 and S2. No DnaK peptides were detected because cell proteins of $\mathrm{O} 157$ strain ATCC 700,728 were used in the affinity spectrometry to avoid the interference from DnaK.

OmpC is known as an osmotic-responsive outer membrane porin (Hamner et al. 2013). Several OmpC structures of $E$. coli have been published and are available in the PDB database. Further analysis of ECO157 OmpC (Accession: QEQ39178.1) sequences with this E. coli OmpC showed that $E$. coli 2 IXX had the highest homology $(92.37 \%)$ and sequence coverage (94\%) to ECO157 OmpC, indicating the
Fig. 2 A Two-dimensional electrophoresis (2-DE) of E. coli O157: $\mathrm{H} 7$ whole-cell protein strained by Coomassie brilliant blue. B Western blot of mAb $2 \mathrm{G} 12$ with the 2-DE gel

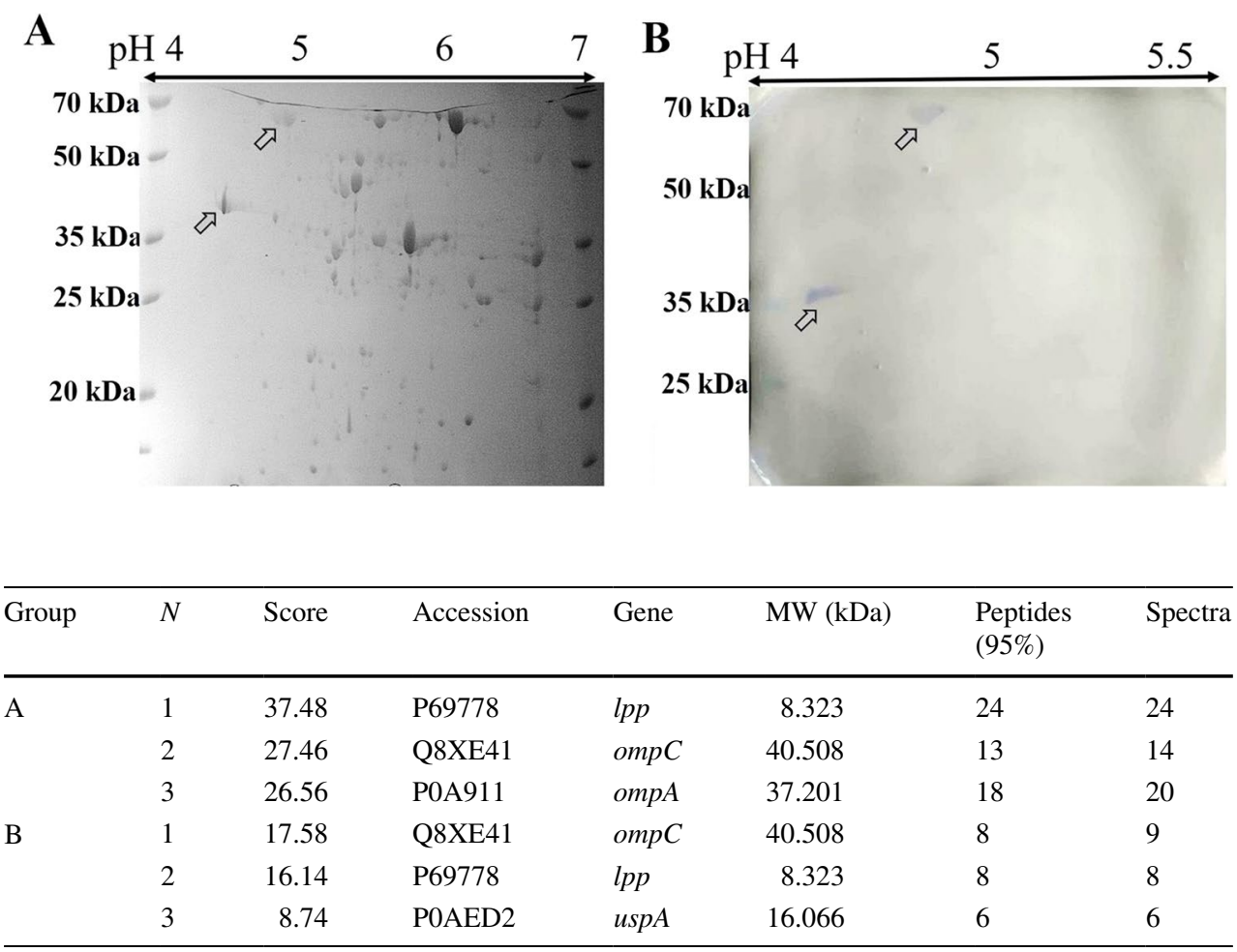

\begin{tabular}{llllllll}
\hline Group & $N$ & Score & Accession & Gene & MW (kDa) & $\begin{array}{l}\text { Peptides } \\
(95 \%)\end{array}$ & Spectra \\
\hline A & 1 & 37.48 & P69778 & lpp & 8.323 & 24 & 24 \\
& 2 & 27.46 & Q8XE41 & ompC & 40.508 & 13 & 14 \\
& 3 & 26.56 & P0A911 & ompA & 37.201 & 18 & 20 \\
B & 1 & 17.58 & Q8XE41 & ompC & 40.508 & 8 & 9 \\
& 2 & 16.14 & P69778 & lpp & 8.323 & 8 & 8 \\
& 3 & 8.74 & P0AED2 & uspA & 16.066 & 6 & 6 \\
\hline
\end{tabular}

Table 1 The identified proteins of ECO157 by IAC and LCMS/MS with $260 \mu \mathrm{g}$ trypsin (group A) or $520 \mu \mathrm{g}$ trypsin (group B) added 


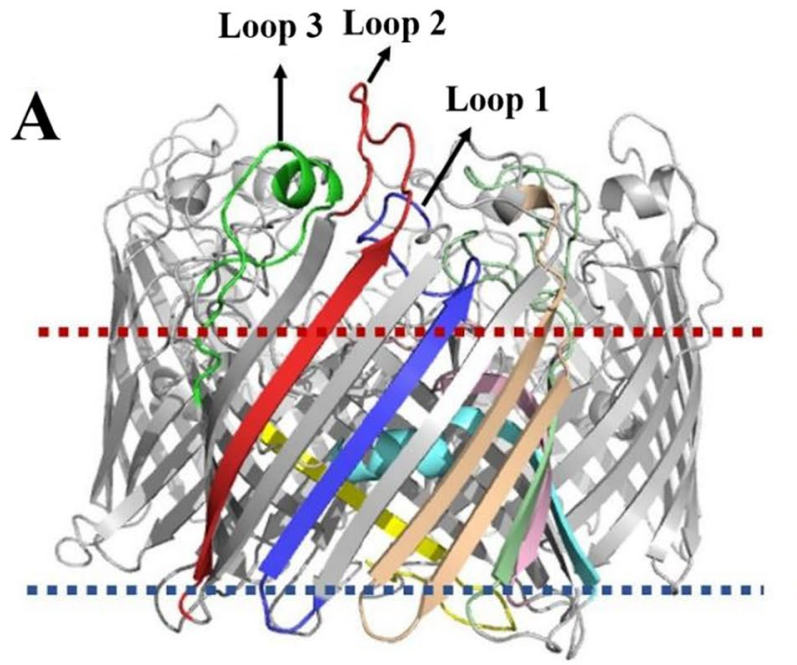

Trypsin $260 \mu g$ (14 peptides)

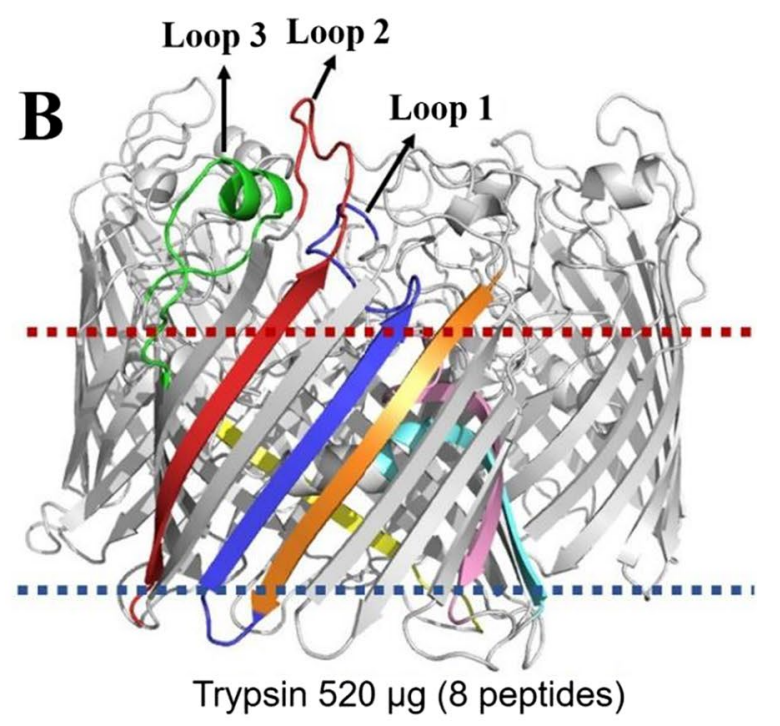

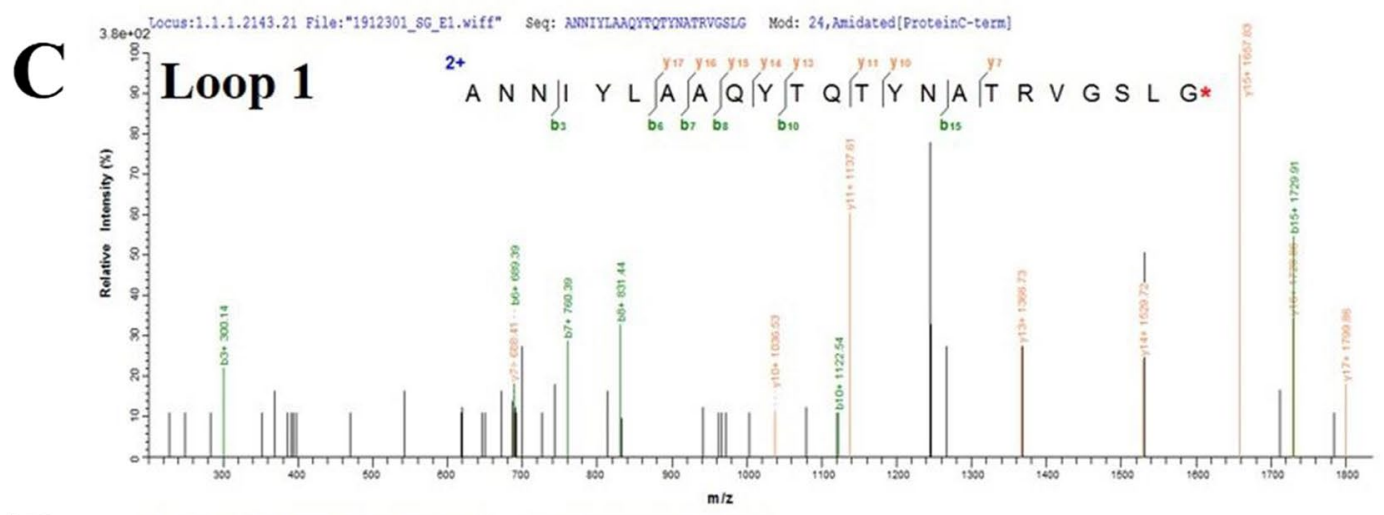

D
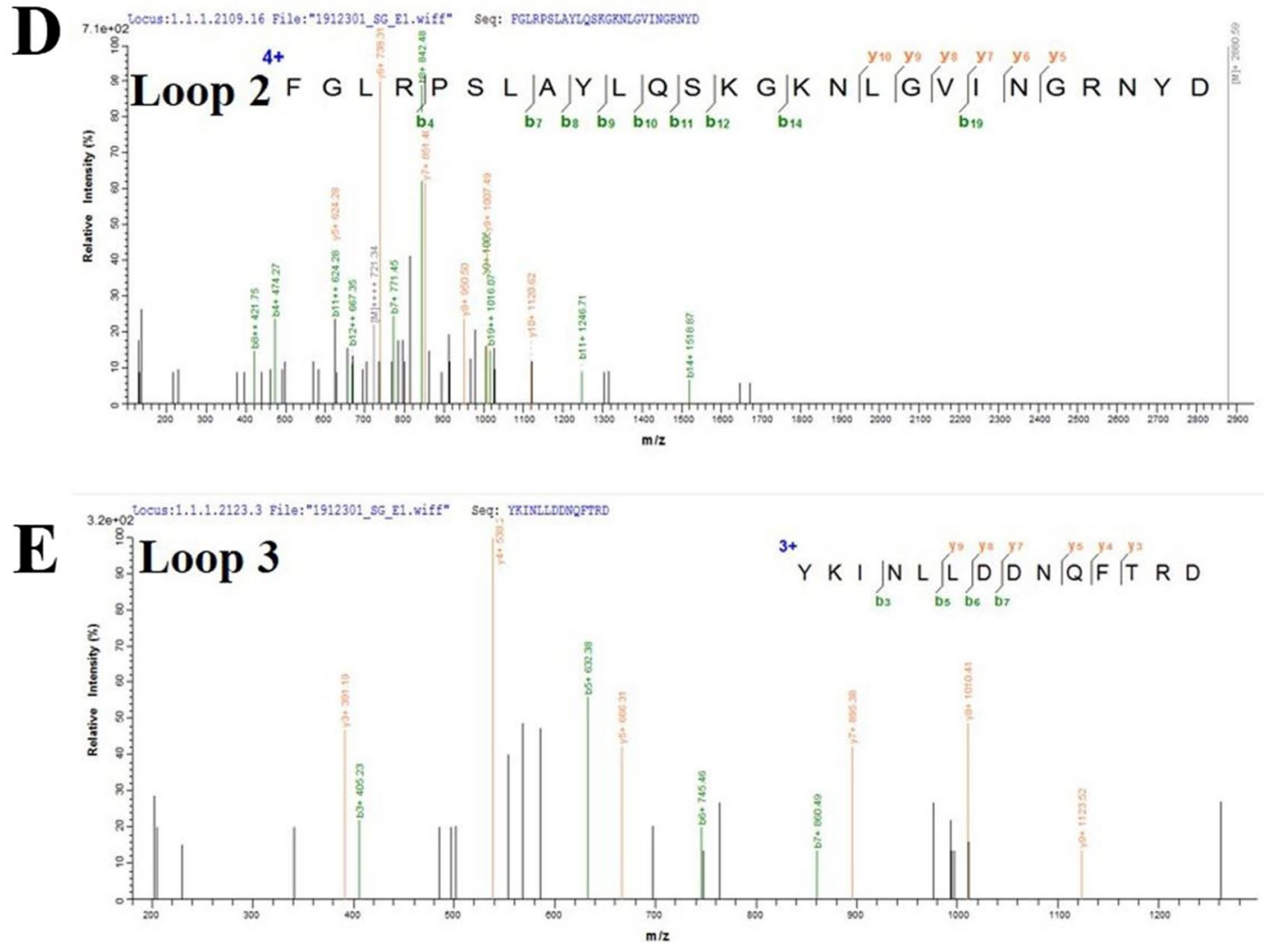
4 Fig. 3 A The location of 14 peptides identified on E. coli OmpC (2IXX) in group A; $\mathbf{B}$ the location of eight peptides identified on $E$. coli OmpC (2IXX) in group B; C-D the mass spectrogram of peptide with extracellular loop1 (C), loop2 (D), and loop3 (E). Loops 1,2 , and 3 are labeled with blue, red, and green color respectively in Fig. 2A and B. In Fig. 2C-E, "FGLRPSLAYLQSKGKNLGVINGRNYD" is 286-311aa and is indicated with red signal; "GNKLDLYGKVD" is 29-39aa and the signal is labeled with yellow; "NFMQQRGNGFATYRNTD" is 140-156aa and is shown by pink signal; "RAETYTGGLKYD" is 234-245aa and its signal is in orange; "VGSFDYGRNYGVVYD" is 106-120aa and shown with cyan color signal; "NQFTRDAGINTD" is 345-356aa and indicated with in green signal; "ANNIYLAAQYTQTYNATRVGSLG" is 246268aa and its signal is blue; "YKINLLDDNQFTRD" is 337-350aa and labeled with green signals

high similarity among these structures. With the topology information available about 2IXX in the OPM database (Supplemental Figure S2), 14 eluted peptides (Fig. 3A) from group A and eight identified peptides (Fig. 3B) from group $\mathrm{B}$ were identified on the OmpC (2IXX) structure. Figure 3A and $\mathrm{B}$ reveals that the loop structure of three adjacent peptides, including "ANNIYLAAQYTQTYNATRVGSLG" (246-268aa, blue, loop1), "FGLRPSLAYLQ- SKGKNLGVINGRNYD" (286-311aa, red, loop2), and "YKINLLDDNQFTRDAGINTD" (337-356aa, green, loop3), were exposed on the surface of the outer membrane. The other peptides were buried in the phospholipid bilayer. Figure $3 \mathrm{C}, \mathrm{D}$, and E shows the MS/MS spectrum of the three long peptides: loop1 (blue), loop2 (red), and loop3 (green).

\section{Epitope mapping of $2 \mathrm{G} 12$ against EC0157 OmpC and its sequence homology}

A peptide library of the three extracellular loops was synthesized to study the exact mAb 2G12 epitope. Especially, six overlapping peptides of loop 2 that showed the highest precursor signal in group B were synthesized at the length of 6 with offsets of 2 (Fig. 4A). Results from epitope mapping by indirect ELISA (Fig. 4B) showed that positive reactions were observed with the short peptide 2.4 (LGVING), the long-form of peptide 2 (QSKGKNLGVINGRNYD), and peptide 1 (TQTYNATRVGSLG). These results showed that the extracellular parts of loop 2 and loop 1 were recognized by $\mathrm{mAb} 2 \mathrm{G} 12$.

To better understand the specificity of $\mathrm{mAb} 2 \mathrm{G} 12$ for ECO157, we further investigated the sequence homology of the three extracellular loops with other tested non-O157 strains that are available in NCBI. These non-O157 strains did not react with mAb $2 \mathrm{G} 12$ at $6 \log _{10} \mathrm{CFU} / \mathrm{mL}$ in our previous study (Wang et al. 2021). Results in Fig. 4C show that the presented sequences of loop 1 (TQTYNATRVGSLG) and loop 3 (YKINLLDDNQFTRD) in 10 out of $11 E$. coli strains shared $81.82 \%$ identity and were conservative (Lipman et al. 2002). Notably, the dotted line in Fig. 4C indicates no amino acid present, and their sequences were identical. By contrast, the sequence of loop 2 (QSKGKNLGVINGRNYD) from ECO157 OmpC was observed with 4-6 amino acid substitutions in the "LGVING" part compared with the other tested non-O157 strains that did not react with $\mathrm{mAb} 2 \mathrm{G} 12$. The unpresented sequence of the eluted peptides corresponding to loops 1, 2, and 3 were also conservative. Further comparison of these three extracellular loops with the OmpC of other non-O157 bacteria (homology ranging from 62 to $90 \%$ in overall BLAST) showed similar results (Supplemental Figure S3), with both loop 1 and loop 3 being conservative and the "LGVING" part of loop 2 highly variable. Analysis of the published OmpC structures of E. coli (2IXX, 2J1N) and $S$. Typhimurium (3UPG) showed that the sequence difference (yellow dots) of ECO157 from these strains was mainly located on loop 2 (Fig. 4D). Figure 4E indicates that the structural differences of the three extracellular OmpC loops from E. coli strains and $S$. Typhimurium were mainly attributed to the sequence, length, and position of loop 2. These results revealed that the "LGVING" part of loop 2 on OmpC was the dominant part that contributed to the specificity of mAb $2 \mathrm{G} 12$ of ECO157.

\section{The availability of epitopes under different simulated stressful conditions}

The availability of OmpC epitopes when ECO157 is grown in different stressful conditions needs to be evaluated since their availability directly impacts the binding efficacy between ECO157 cells and antibodies, especially pathogens in real food samples are typically under unfavorable conditions and in low concentrations. Figure 5A shows that, compared with the normal BPW group (1\% salt, $\mathrm{pH} 7.2)$, the growth of ECO157 was inhibited at higher salt concentrations (2\% and $4 \%$ ). Low nutrition levels (which was mimicked by $0.1 \%(\mathrm{~m} / \mathrm{v})$ peptone water) also significantly slowed down the growth. However, BPW with a $\mathrm{pH}$ value adjusted to 4.3 did not inhibit the growth of ECO157. The plate counting results in Supplemental Figure S4 show that the inoculated level of ECO157 was $7.17 \log _{10} \mathrm{CFU} / \mathrm{mL}$, and the cell concentration of ECO157 in BPW with different growth factors both increased except when it is supplemented with $4 \% \mathrm{NaCl}$. The results of whole-cell ELISA with ECO157 (7.0 $\log _{10} \mathrm{CFU} / \mathrm{mL}$ ) in Fig. 5B show that, compared with the ECO157 grown in normal BPW $\left(\mathrm{OD}_{450}=2.361 \pm 0.064\right)$, the binding of mAb $2 \mathrm{G} 12(1 \mathrm{~K}, 4 \mu \mathrm{g} / \mathrm{mL})$ increased as the salt concentrations increased from $1 \%\left(\mathrm{OD}_{450}=2.508 \pm 0.093\right)$ to $4 \%\left(\mathrm{OD}_{450}=2.517 \pm 0.026\right)$. In the meantime, the binding of $\mathrm{mAb} 2 \mathrm{G} 12$ with ECO157 grown in BPW with $\mathrm{pH}$ $4.3\left(\mathrm{OD}_{450}=2.355 \pm 0.040\right)$ and $0.1 \%$ peptone water $\left(\mathrm{OD}_{450}=2.394 \pm 0.088\right)$ slightly decreased. These results indicated the good availability and stability of this OmpC epitope for the recognition and binding with mAb 2G12. 


\section{A •Pep1 Biotin-SGSG-TQTYNATRVGSLG \\ - Pep2 Biotin-SGSG-QSKGKNLGVINGRNYD \\ - Pep2.1 Biotin-SGSG-QSKGKN \\ -Pep2.2 Biotin-SGSG-KGKNLG \\ -Pep2.3 \\ - Pep2.4 \\ Biotin-SGSG-KNLGVI \\ - Pep2.5 \\ Biotin-SGSG-LGVING \\ - Pep2.6 \\ Biotin-SGSG-VINGRN \\ -Pep3 Biotin-SGSG-YKINLLDDNQFTRD}

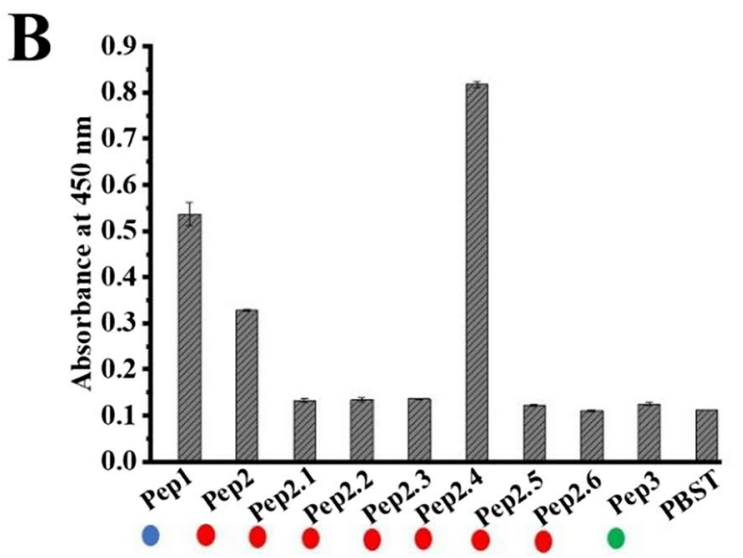

C
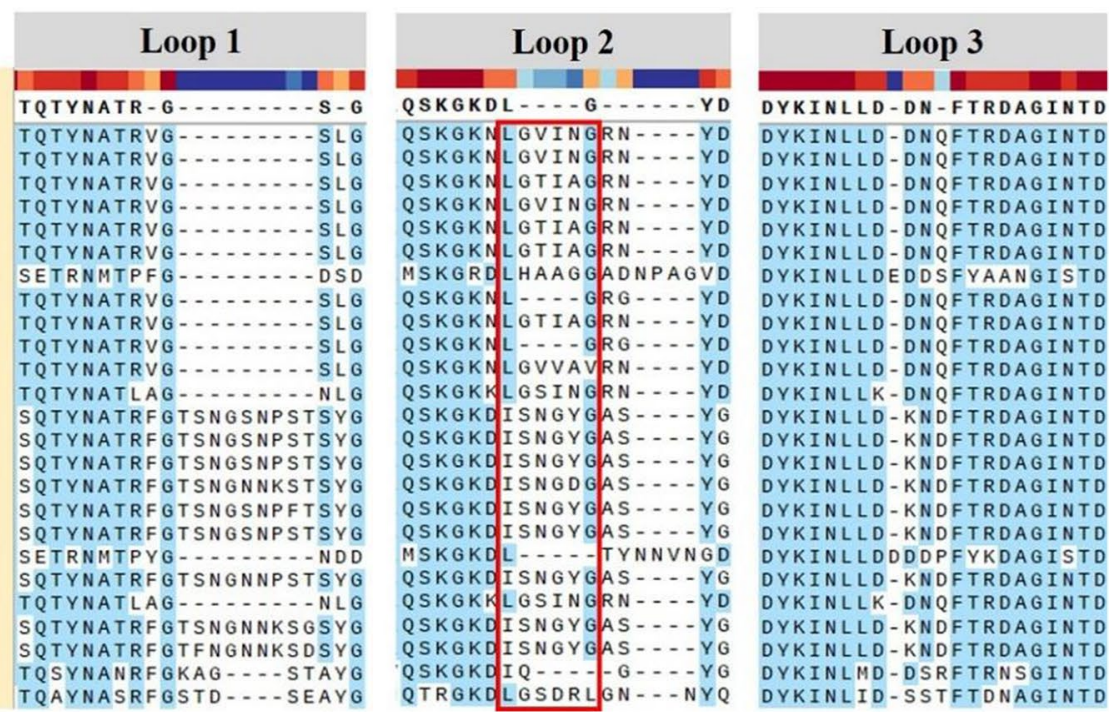

Loop 3

Consensus gb|RXÄ03227.1 OmpC [E. coli O157:H7]

dbj|GEI20863.1 OmpC [E. coli O145:H25]

gb|AHG09653.1 OmpC precursor [E. coli O145:H28]

gb|EZE03917.1 Omp [E. coli O145:H28 str. 2009C-3292]

gb|AWJ28945.1 PhoE [E. coli O121 str. RM8352]

gb|AWJ26910.1 PhoE [E. coli O121 str. RM8352]

gb|EIL23365.1 OmpC [E. coli O111:H11 str. CVM9545]

gb|EAB0383119.1 OmpC [E. coli O103]

gb|AW]31218.1 PhoE [E. coli O103 str. RM8385]

gb|AEP03211.1 OmpC, partial [E. coli O26]

gb|EDM2237822.1 OmpC [s. typhimurium]

ref|NP_461210.1 OmpC [S. typhimurium str. LT2]

gb|EBI0293069.1 OmpC [S. saintpaul]

gb|EBF8661465.1 OmpC [S. saintpaul str. CFSAN000610]

gb|EDF8020360.1 OmpC [S. montevideo]

tpg|HAE9389518.1 OmpC [S. montevideo]

gb|EBL5842033.1 OmpC [S. tennessee]

gb|ECG5350037.1 OmpC [S. tennessee]

gb|EBH27 10454.1 OmpC [S. enteritidis]

gb|EDB4449707.1 OmpC [S. enteritidis]

gb|ECB8874833.1 OmpC [S. anatum]

gb|EBL4835878.1 OmpC [S. anatum]

emb|VTQ52834.1 OmpC [C. jejuni]

TQAYNASRFGSTD -... SEAYG

\begin{tabular}{|c|c|}
\hline Loop 2 & Lo \\
\hline QSKGKDL & DYKINLLD - DN - FTRDAGINTD \\
\hline 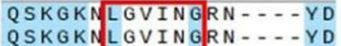 & DYKINLLD-DNQFTRDAG INTD \\
\hline QSKGKNLLGIAGRN R . & D - D N Q F TRDAG IN T D \\
\hline QSKGKNLGVINGRN .... YD & $\begin{array}{l}\text { DYKINLLD-DNQFTRDAGINTD } \\
\text { DYKINLLD-DNQFTRDAGINTD }\end{array}$ \\
\hline GKNLG T I A GRN - . Y Y & DYKINLLD-DNQFTRDAG INTD \\
\hline QSKGKN|LGTIAG|RN - - Y YD & DYKINLLD-DNQFTRDAGINTD \\
\hline MSKGRDLLAAGGADNPAGVD & DYKINLLDEDDSFYAANGISTD \\
\hline QSKGKN/L - - G RG - . Y Y & DYKINLLD-DNQFTRDAGINTD \\
\hline QSKGKN/LGTIAGRN - - Y Y & DYKINLLD-DNQFTRDAGINTD \\
\hline QSKGKN|L...G|RG - . Y YD & DYK I NLLD - DNQFTRDAG INTD \\
\hline QSKGKNLLGVVAVRN - . Y Y D & DYKINLLD-DNQFTRDAGINTD \\
\hline KL GS ING RN - . - Y Y & DYKINLLK - DNQFTRDAG INTD \\
\hline QSKGKDISNGYGAS - - - Y Y & DYK I NLLD - KNDFTRDAG INTD \\
\hline KDIISNGYGAS $\cdots$ Y G & DYKINLLD-KNDFTRDAGINTD \\
\hline QSKGKDISNGYGAS - . Y Y G & DYK I NLLD - KNDFTRDAG INTD \\
\hline QSKGKDISNGDG|AS . . Y Y G & DYKINLLD - KNDFTRDAG INTD \\
\hline KDIISNGYGAS $\cdots$ Y Y & DYKINLLD-KNDFTRDAG INTD \\
\hline QSKGKDISNGYGAS - . - Y YG & DYK I NLLD - KNDFTRDAG INTD \\
\hline MSKGKDL...-TYNNVNGD & DYKINLLDDDDPFYKDAGISTD \\
\hline QSKGKDIISNGYG|AS - & DYKINLLD - KN D FTRDAG INTD \\
\hline QSKGKKLGSINGRN & DYK INLLK - DNQFTRDAG INTD \\
\hline QSKGKDISNGYGAS $\cdots$ Y Y & DYKINLLD - KNDFTRDAG INTD \\
\hline QSKGKDISNGYGAS - - - Y Y & DYK I N L LD - KN DFTR \\
\hline$-Y Y_{G}$ & DYKINLMD - DSRFTRNSG INTD \\
\hline & DYK I NLID \\
\hline
\end{tabular}

ref|NP_311131.1 OmpC [E. coli O157:H7 str. Sakai]

DNQFTRD GKNLG---RG--YD
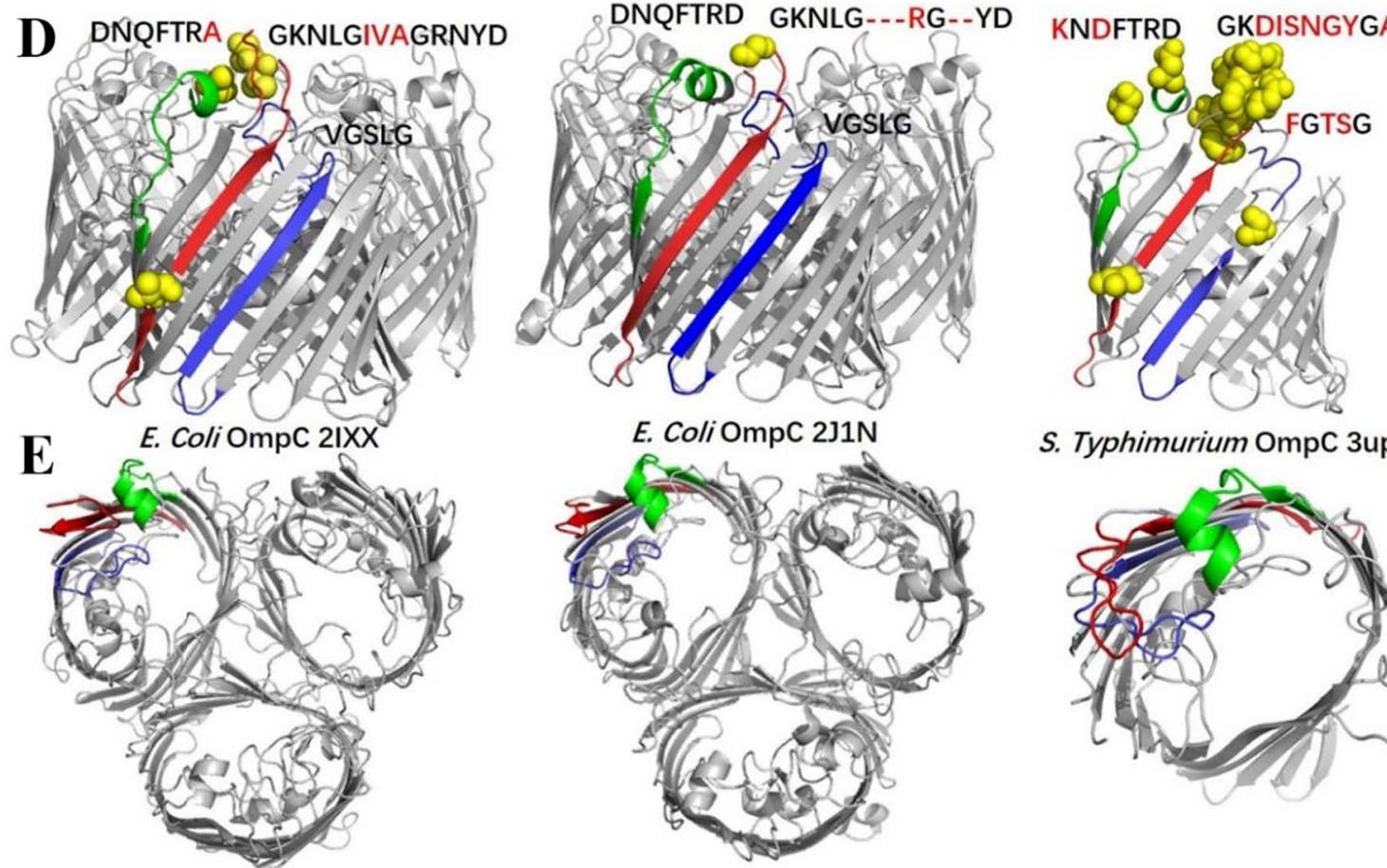

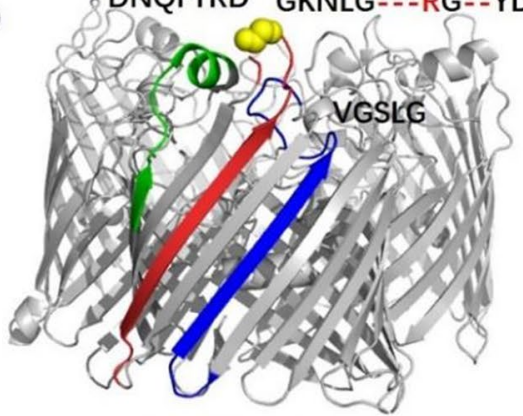

E. Coli OmpC 2J1N

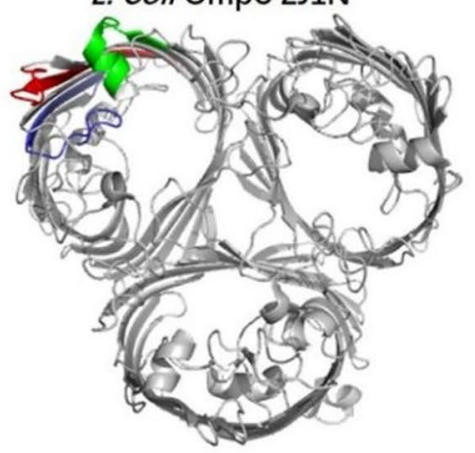

S. Typhimurium OmpC 3upg

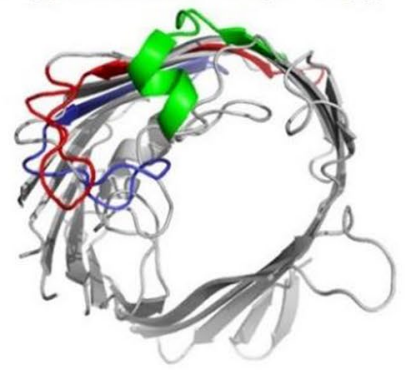


4Fig. 4 A The overlapping peptide library consists of extracellular loops 1, 2, and 3; B epitope mapping by indirect ELISA based on the reaction between antibodies and peptides. Higher absorbance indicates higher binding rate of antibody with the corresponding peptide. C The sequence homology of three extracellular loops of ECO157 OmpC with other tested non-O157 strains; the dotted line indicates that there is no amino acid; the red box shows the high variance of aminol acids in "LGVIN" of loop2 between strains. The sequence variance (D) and orientation difference (E) of these three extracellular loops on OmpC structures of general E. coli (2IXX, 2J1N) and $S$. Typhimurium (3UPG)

\section{Discussion}

Wang et al. (2020) revealed that the newly identified $\mathrm{mAb}$ 2G12 had good specificity for recognizing ECO157 and it bound with a high abundance protein of approximately $35 \mathrm{kDa}$. In addition, mAb 2G12 bound with an approximately $70 \mathrm{kDa}$ protein of ECO157 CICC 21,530 . However, little is known about the identity of these proteins. In this study, the target protein and the epitope of mAb $2 \mathrm{G} 12$ were first purified and isolated for better understanding its specificity at the protein and sequence levels. The purification and quantification of the protein by acetone precipitation, 2D clean-up kit, and 2D quant-kit were essential to remove nucleic acids, polysaccharides, and salt, which usually cause smears on the 2-DE gel (Görg et al. 2004). The size of the OmpC was slightly larger than $35 \mathrm{kDa}$ (pI at around 4.5) based on its position on the 2-DE or SDSPAGE gel. This location on the 2-DE gel was comparable with the proteomics of E. coli reported by Molloy (Molloy et al. 2000). Based on MALDI-TOP-MS, the size of OmpC was $40.48 \mathrm{kDa}$ ( $\mathrm{pI} 4.5$ ). The size differences seen between the SDS-PAGE result and the MALDI-TOF-MS results were expected as previous studies have shown the estimation of protein MW by SDS-PAGE might not be as precise as MALDI-TOF-MS (Liu et al. 2010). Chaperone DnaK located in the peripheral or inner membrane was detected in WB as protein samples were purified directly from wholecell lysates were used, and chaperone DnaK is involved in binding to nascent or unfolded polypeptides (Calloni et al. 2012). The direct identification of the target protein band $(\sim 35 \mathrm{kDa})$ of ATCC 35,150 in the SDS-PAGE gel by in-gel digestion and the LC-MS/MS also showed that the leading protein was OmpC (Supplemental Table S3). As reported previously by Wang et al. (2021), the $70 \mathrm{kDa}$ band was only observed for ECO157 CICC 21,530 and the $~ 35 \mathrm{kDa}$ band was mainly from other ECO157 strains. All of these above results revealed that $\mathrm{OmpC}$ was the target outer membrane protein of $\mathrm{mAb} 2 \mathrm{G} 12$.

The epitope excision strategy of IAC-based affinity mass spectrometry was successful in our study. The decreased bound peptides on the column with more trypsin (used in group B) indicated more thorough hydrolysis and more efficient identification of candidate target peptides (Supplemental Tables S1 and S2). Trypsin cleaves exclusively $\mathrm{C}$-terminal to arginine $(\mathrm{R})$ and lysine $(\mathrm{K})$ residues except when they are followed by a proline (P) (Olsen et al. 2004). The residue cleavage sites in these peptides suggested that they were protected from hydrolysis by the $\mathrm{mAb}$ in groups $\mathrm{A}$ and $\mathrm{B}$. The peptide (red) with a higher precursor signal (1269.36) in group B after IAC and LC-MS/MS (Fig. 3D) indicated a relatively higher residue amount in the column before elution, and it was well protected by the mAb. Our results also showed that a theoretical molecular ratio of enzyme to protein at 2:1 for $30 \mathrm{~min}$ (group B) was essential to ensure thorough cleavage of protein during IAC. The in situ digestion with the optimal amount of trypsin in IAC columns was the key to cleave the unrelated peptides and protect the epitope from hydrolysis (Table 1). In the previous work, the in situ digestion of recombinant PD-L1 protein in IAC with molecular ratio of trypsin to protein at 1.63:1 also successfully identified the epitope resides (Hao et al. 2015).

To simplify the sample preparation, a protein cocktail purified from ECO157 cell lysates was used for IAC in this study. In many previous epitope identification studies, recombinant protein samples were usually used (47 out of 52 studies), although native protein ( 3 out of 52 reports) and cell lysates ( 2 out of 52 reports) were also adopted (Opuni et al. 2018; Rinaldi et al. 2019). The detection of some impurities like lpp (8.3 kDa, pI 9.3) and OmpA (37.2 kDa, pI 5.99) with nonmatched $\mathrm{pI}$ values and MWs in this study indicated that there was non-specific binding with the relatively complex cell protein samples, which may complicate the analysis of results from affinity mass spectrometry. This potential drawback was overcome by two critical steps in our epitope identification. The first one was that the target protein was identified by 2-DE, WB, and MALDI-TOF/ TOF before affinity mass spectrometry. By doing so, the target protein was revealed to be the OmpC on the cell outer membrane. The other step was that, with more trypsin added in group B and a more thorough digestion, the number of detected OmpC peptides and spectra ranked first among the all the peptides and spectra.

Fourteen eluted peptides in group A and eight eluted peptides in group B (ranged from 11 to 25aa) after LC-MS/MS challenged the epitope mapping because of the need for a relatively large overlapping peptide library. The location of these peptides on the highly homogenous OmpC structure and the topology information clearly showed that only three peptides on the extracellular side of the outer membrane were available for antibody binding. This was based on the fact that many Omps are inserted into the cell membrane, and only the extracellular parts are involved in the interaction with the host cell and antibodies (Noinaj et al. 2013; Rollauer et al. 2015). Protein structure and topology information identified in this study were further confirmed by 
Fig. 5 A The growth curve of ECO157 (indicated by OD values) under different osmotic pressure, low nutrition level, and low $\mathrm{pH}$ level in buffered peptone water (PBS). B The binding of OmpC mAb 2G12 against ECO157 grown in different osmotic pressure, low nutrition level, and low $\mathrm{pH}$ level in buffered peptone water; the ECO157 was coated at $7.0 \log _{10}$ $\mathrm{CFU} / \mathrm{mL}$ on the microplate

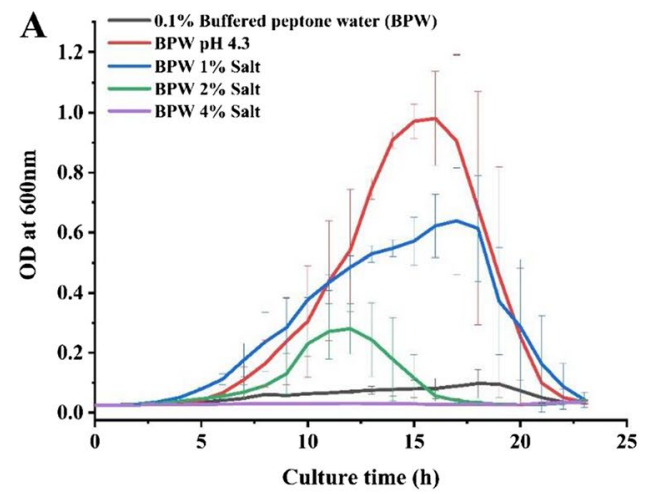

information obtained from the PDB and OPM databases. In addition, our results match well with the previous report by Lou et al. (2011). In this study, the experimentally determined crystal structures of five OmpC (2XE1, 2XE2, 2XE3, 2XE5, 2XG6) from clinical $E$. coli mutants were very close to the OmpC structure (7JZ3) of E. coli K12. These structures also showed that there were eight extracellular loops on OmpC while three of the eluted peptides in our study located on the extracellular loops as well.

The epitope mapping results by indirect ELISA showed that the OmpC mAb 2G12 reacted with the synthesized peptides of loop 2 (LGVING) and loop 1 (TQTYNATRVGSLG). Both were modified with spacer-arm-linked biotin at the $\mathrm{N}$ terminal and attached to the avidin-coated microplate. The absorbance with the extracellular parts of loop $2\left(\mathrm{OD}_{450}=0.817 \pm 0.011\right)$ was higher than loop 1 $\left(\mathrm{OD}_{450}=0.536 \pm 0.009\right)$. Because of the wide distribution of the OmpR/EnvZ two-component system in bacteria, OmpC is conservative between different serotypes of $E$. coli and other Gram-negative bacteria. The sequence and the structural base for the specificity of mAb $2 \mathrm{G} 12$ were further checked by sequence BLAST with strains not reacting with mAb 2G12. As shown in Fig. 4C, the extracellular part of loop 1 was conservative in many of the tested $E$. coli strains, while the "LGVING" part of loop 2 showed high amino acid variance. The same results were obtained in the overall BLAST analysis of OmpC sequences of all the non-O157 strains with clear classification at the species level (Supplemental Figure S3). Therefore, the specificity of mAb 2G12 was largely attributed to the more accessible and specific peptide "LGVING" on loop 2.

The overall BLAST of the target peptides with non-tested strains found that Shigella strains and E. coli $\mathrm{O} 145$ strains have the identical sequence of "LGVING" on loop 2 (Supplemental Figure S3). This indicates possible cross-reaction between these strains with mAb 2G12. However, our previous whole-cell ELISA study of three Shigella strains did not show any reaction with $\mathrm{mAb} 2 \mathrm{G} 12$ and an E. coli O145 strain weakly reacted with mAb 2G12 (Wang et al. 2021). The antibody specificity against bacteria cells is determined by many factors, such as the physical barrel of outer polysaccharides (Storek et al. 2018). According to a recent report by Domínguez-Medina (Domínguez-Medina et al. 2020), the structure difference of the $\mathrm{O}$ antigen resulted in different pore sizes and structures above the porin protein, which restricted IgG binding with Omp even when there was only a single amino acid residue substitution. Therefore, the antibody specificity was shaped by the sequence specificity of the two extracellular loops and further improved by the physical barrel of outer polysaccharides.

Internal and external factors associated with food or food processing environment pose many stresses to bacteria and may alter the expression of surface receptors (Hahm and Bhunia 2006). These surface changes could, in turn, impact the binding affinity of antibodies and the recovery of viable bacterial cells in pre-analytical sample processing (Dwivedi and Jaykus 2011). For example, starved ECO157 incubated in water for a long period resulted in the loss of $\mathrm{O}$ antigens in many cells, suggesting that immunologic methods based on the $\mathrm{O} 157 \mathrm{O}$ antigen may not be able to isolate the verocytotoxin-producing $E$. coli under this condition (HaraKudo et al. 2000). E. coli incubated in low (3.5) or high (9) $\mathrm{pH}$ for $24 \mathrm{~h}$ has been shown to produce a much smaller signal when detected with a bead-based immunoassay (Denes and Wiedmann 2014). After $6 \mathrm{~h}$ and $24 \mathrm{~h}$ exposure to the combined stresses of $\mathrm{pH} 5.5$ and $3.5 \% \mathrm{NaCl}$ at $4{ }^{\circ} \mathrm{C}$, antibody reactions to ECO157 respectively showed 33\% and $17 \%$ reductions (Hahm and Bhunia 2006). Previous studies reported that the expression of OmpC could be regulated by osmotic stresses, $\mathrm{pH}$ values, temperatures, nutrient levels, and the gut environment (Kojima and Nikaido 2014; Lin et al. 2002; Özkanca and Flint 2002; Sleator and Hill 2002; Thomas and Booth 1992).

In this study, to analyze the availability of the epitope with $\mathrm{mAb} 2 \mathrm{G} 12$ under different stressful environments in food, the clinical ECO157 isolate LJH643 obtained from a cantaloupe outbreak was used because it is directly related with food poisoning. Our results showed that binding of OmpC antibody with ECO157 slightly increased when the bacteria were grown in an environment with higher 
osmolarity and slightly decreased when grown in an environment with lower $\mathrm{pH}$ and nutrition level, which indicated that the expression and availability of the OmpC epitope were relatively stable for the wide application of immunomagnetic separation and immunoassays.

In summary, mAb $2 \mathrm{G} 12$ have shown good specificity to ECO157. The target protein and epitope of $\mathrm{mAb} 2 \mathrm{G} 12$ were identified by combining 2-DE, WB, MALDI-TOF/ TOF, affinity mass spectrometry, epitope mapping, and protein structure, topology, and sequence homology analysis. The epitope consists of two extracellular loops of OmpC, the ECO157-specific "LGVING," and an adjacent "TQTYNATRVGSLG." "TQTYNATRVGSLG" was found to be more conservative than "LGVING." The ECO157specific extracellular loop with the peptide "LGVING" was the dominant part contributing to antibody specificity. The availability and accessibility of "LGVING" is stable when ECO157 is grown under various food environment conditions/stresses. The loop structure with "LGVING" present on OmpC serves as a promising target for the preparation of ECO157 diagnostic antibodies with good specificity. Furthermore, the affinity mass spectrometry and protein topology approaches were proven to be efficient methods for studying epitopes and their reactions with antibodies.

Supplementary Information The online version contains supplementary material available at https://doi.org/10.1007/s00253-021-11511-8.

Author contribution WW, SP, and LW designed the study and experiments. WW, XZ, XL, and YS conducted the experiment. WW, XZ, and JL collected the data and conducted data analyses. WW and YS drafted the manuscript. LW reviewed and edited the manuscript. All authors read and approved the manuscript.

Funding This work is supported by the National Natural Science Foundation of China (Grant No. 31701680), the Natural Science Foundation of Jiangsu Province of China (Grant No. SBK2017041308), the Jiangsu Government Scholarship for Overseas studies (JS-2019-309), the Jiangsu Planned Projects for Postdoctoral Research Funds, Openend Funds of Jiangsu Key Laboratory of Marine Bioresources and Environment, Jiangsu Ocean University (SH20201202), and the Priority Academic Program Development of Jiangsu Higher Education Institutions. In addition, the authors appreciate financial support and startup funds provided by the Department of Food Science and Technology at the University of California Davis.

Data availability All major data generated and analyzed in this study are included in this manuscript and its supplementary information files. Other data is available from the first and corresponding authors on reasonable request.

\section{Declarations}

Ethical statement This article does not contain any studies with human participants or animals performed by any of the authors.

Conflict of interest The authors declare no competing interests.
Open Access This article is licensed under a Creative Commons Attribution 4.0 International License, which permits use, sharing, adaptation, distribution and reproduction in any medium or format, as long as you give appropriate credit to the original author(s) and the source, provide a link to the Creative Commons licence, and indicate if changes were made. The images or other third party material in this article are included in the article's Creative Commons licence, unless indicated otherwise in a credit line to the material. If material is not included in the article's Creative Commons licence and your intended use is not permitted by statutory regulation or exceeds the permitted use, you will need to obtain permission directly from the copyright holder. To view a copy of this licence, visit http://creativecommons.org/licenses/by/4.0/.

\section{References}

Calloni G, Chen T, Schermann Sonya M, Chang H-c, Genevaux P, Agostini F, TartagliaGian G, Hayer-Hartl M, Hartl FU (2012) DnaK functions as a central hub in the $E$. coli chaperone network. Cell Rep 1(3):251-264. https://doi.org/10.1016/j.celrep.2011.12. 007

Casina VC, Hu W, Hanby HA, Pickens B, Mayne L, Ostertag E, Kacir S, Siegel DL, Englander SW, Zheng XL (2014) Autoantibody epitope mapping by hydrogen-deuterium exchange mass spectrometry at nearly single amino acid residue resolution reveals novel exosites on ADAMTS13 critical for substrate recognition and mechanism of autoimmune thrombotic thrombocytopenic purpura. Blood 124(21):108. https://doi.org/10.1182/blood.V124. 21.108 .108

Compton SJ, Jones CG (1985) Mechanism of dye response and interference in the Bradford protein assay. Anal Biochem 151(2):369374. https://doi.org/10.1016/0003-2697(85)90190-3

Denes T, Wiedmann M (2014) Environmental responses and phage susceptibility in foodborne pathogens: implications for improving applications in food safety. Curr Opin Biotechnol 26:45-49. https://doi.org/10.1016/j.copbio.2013.09.001

Desai SK, Kenney LJ (2019) Switching lifestyles is an in vivo adaptive strategy of bacterial pathogens. Front Cell Infect Microbiol 9:421. https://doi.org/10.3389/fcimb.2019.00421

Dobson L, Reményi I, Tusnády GE (2015) CCTOP: a Consensus Constrained TOPology prediction web server. Nucleic Acids Res 43(W1):W408-W412. https://doi.org/10.1093/nar/gkv451

Domínguez-Medina CC, Pérez-Toledo M, Schager AE, Marshall JL, Cook CN, Bobat S, Hwang H, Chun BJ, Logan E, Bryant JA, Channell WM, Morris FC, Jossi SE, Alshayea A, Rossiter AE, Barrow PA, Horsnell WG, MacLennan CA, Henderson IR, Lakey JH, Gumbart JC, López-Macías C, Bavro VN, Cunningham AF (2020) Outer membrane protein size and LPS O-antigen define protective antibody targeting to the Salmonella surface. Nat Commun 11(1):851. https://doi.org/10.1038/s41467-020-14655-9

Dwivedi HP, Jaykus L-A (2011) Detection of pathogens in foods: the current state-of-the-art and future directions. Crit Rev Microbiol 37(1):40-63. https://doi.org/10.3109/1040841X.2010.506430

Forsström B, Axnäs BB, Stengele K-P, Bühler J, Albert TJ, Richmond TA, Hu FJ, Nilsson P, Hudson EP, Rockberg J (2014) Proteomewide epitope mapping of antibodies using ultra-dense peptide arrays. Mol Cell Proteomics 13(6):1585-1597. https://doi.org/ 10.1074/mcp.M113.033308

Görg A, Weiss W, Dunn MJ (2004) Current two-dimensional electrophoresis technology for proteomics. Proteomics 4(12):3665-3685. https://doi.org/10.1002/pmic.200401031

Gourlay L, Peri C, Bolognesi M, Colombo G (2017) Structure and computation in immunoreagent design: from diagnostics to vaccines. Trends Biotechnol 35(12):1208-1220. https://doi.org/10. 1016/j.tibtech.2017.06.018 
Graeber E, Korkhov VM (2020) Affinity purification of membrane proteins. In: Perez C, Maier T (eds) Expression, purification, and structural biology of membrane proteins. Springer, US, New York, pp 129-137. https://doi.org/10.1007/978-1-0716-0373-4_9

Hahm B-K, Bhunia AK (2006) Effect of environmental stresses on antibody-based detection of Escherichia coli O157:H7, Salmonella enterica serotype Enteritidis and Listeria monocytogenes. J Appl Microbiol 100(5):1017-1027. https://doi.org/10.1111/j. 1365-2672.2006.02814.x

Hamner S, McInnerney K, Williamson K, Franklin MJ, Ford TE (2013) Bile salts affect expression of Escherichia coli $\mathrm{O} 157: \mathrm{H} 7$ genes for virulence and iron acquisition, and promote growth under iron limiting conditions. PLoS ONE 8(9):e74647. https://doi.org/10. 1371/journal.pone. 0074647

Hao G, Wesolowski JS, Jiang X, Lauder S, Sood VD (2015) Epitope characterization of an anti-PD-L1 antibody using orthogonal approaches. J Mol Recognit 28(4):269-276. https://doi.org/10. $1002 /$ jmr. 2418

Hara-Kudo Y, Miyahara M, Kumagai S (2000) Loss of O157 O antigenicity of verotoxin-producing Escherichia coli O157: H7 surviving under starvation conditions. Appl Environ Microbiol 66(12):5540-5543. https://doi.org/10.1128/AEM.66.12.55405543.2000

Heuzenroeder MW, Barton MD, Vanniasinkam T, Phumoonna T (2009) Linear B-cell epitope mapping using enzyme-linked immunosorbent assay for libraries of overlapping synthetic peptides. In: Schutkowski M, Reineke U (eds) Epitope mapping protocols, 2nd edn. Humana Press, Totowa, pp 137-144. https://doi.org/10.1007/ 978-1-59745-450-6_10

Hollingshead S, Jongerius I, Exley RM, Johnson S, Lea SM, Tang CM (2018) Structure-based design of chimeric antigens for multivalent protein vaccines. Nat Commun 9(1):1051. https://doi.org/10.1038/ s41467-018-03146-7

Iuraşcu M-I, MarroquinBelaunzanar O, Cozma C, Petrausch U, Renner C, Przybylski M (2016) An HLA-B27 homodimer specific antibody recognizes a discontinuous mixed-disulfide epitope as identified by affinity-mass spectrometry. J Am Soc Mass Spectrom 27(6):1105-1112. https://doi.org/10.1021/jasms.8b05288

Katayama H, Nagasu T, Oda Y (2001) Improvement of in-gel digestion protocol for peptide mass fingerprinting by matrix-assisted laser desorption/ionization time-of-flight mass spectrometry. Rapid Commun Mass Spectrom 15(16):1416-1421. https://doi.org/10. 1002/rcm.379

Kojima S, Nikaido H (2014) High salt concentrations increase permeability through OmpC channels of Escherichia coli. J Biol Chem 289(38):26464-26473. https://doi.org/10.1074/jbc.M114.585869

Kowalsky CA, Faber MS, Nath A, Dann HE, Kelly VW, Liu L, Shanker P, Wagner EK, Maynard JA, Chan C (2015) Rapid fine conformational epitope mapping using comprehensive mutagenesis and deep sequencing. J Biol Chem 290(44):26457-26470. https://doi. org/10.1074/jbc.M115.676635

Law JWF, Ab Mutalib NS, Chan KG, Lee LH (2015) Rapid methods for the detection of foodborne bacterial pathogens: principles, applications, advantages and limitations. Front Microbiol 5:770. https://doi.org/10.3389/fmicb.2014.00770

Lin J, Huang S, Zhang Q (2002) Outer membrane proteins: key players for bacterial adaptation in host niches. Microb Infect 4(3):325331. https://doi.org/10.1016/S1286-4579(02)01545-9

Lipman DJ, Souvorov A, Koonin EV, Panchenko AR, Tatusova TA (2002) The relationship of protein conservation and sequence length. BMC Evol Biol 2(1):20. https://doi.org/10.1186/ 1471-2148-2-20

Liu L, Ikeda TM, Branlard G, Peña RJ, Rogers WJ, Lerner SE, Kolman MA, Xia X, Wang L, Ma W, Appels R, Yoshida H, Wang A, Yan Y, He Z (2010) Comparison of low molecular weight glutenin subunits identified by SDS-PAGE, 2-DE, MALDI-TOF-MS and
PCR in common wheat. BMC Plant Biol 10(1):124. https://doi. org/10.1186/1471-2229-10-124

Lomize MA, Pogozheva ID, Joo H, Mosberg HI, Lomize AL (2012) OPM database and PPM web server: resources for positioning of proteins in membranes. Nucleic Acids Res 40(D1):D370-D376. https://doi.org/10.1093/nar/gkr703

Lou H, Chen M, Black SS, Bushell SR, Ceccarelli M, Mach T, Beis K, Low AS, Bamford VA, Booth IR, Bayley H, Naismith JH (2011) Altered antibiotic transport in OmpC mutants isolated from a series of clinical strains of multi-drug resistant E. coli. PLoS One 6(10):e25825. https://doi.org/10.1371/journal.pone.0025825

Lu X, DeFelippis MR, Huang L (2009) Linear epitope mapping by native mass spectrometry. Anal Biochem 395(1):100-107. https:// doi.org/10.1016/j.ab.2009.08.018

Malito E, Biancucci M, Faleri A, Ferlenghi I, Scarselli M, Maruggi G, Surdo PL, Veggi D, Liguori A, Santini L (2014) Structure of the meningococcal vaccine antigen NadA and epitope mapping of a bactericidal antibody. PNAS 111(48):17128-17133. https://doi. org/10.1073/pnas.1419686111

Moise A, André S, Eggers F, Krzeminski M, Przybylski M, Gabius H-J (2011) Toward bioinspired galectin mimetics: identification of ligand-contacting peptides by proteolytic-excision mass spectrometry. J Am Chem Soc 133(38):14844-14847. https://doi.org/ $10.1021 / \mathrm{ja} 201967 \mathrm{v}$

Molloy MP, Herbert BR, Slade MB, Rabilloud T, Nouwens AS, Williams KL, Gooley AA (2000) Proteomic analysis of the Escherichia coli outer membrane. Eur J Biochem 267(10):2871-2881. https://doi.org/10.1046/j.1432-1327.2000.01296.x

Najar TA, Khare S, Pandey R, Gupta SK, Varadarajan R (2017) Mapping protein binding sites and conformational epitopes using cysteine labeling and yeast surface display. Structure 25(3):395406. https://doi.org/10.1016/j.str.2016.12.016

Noinaj N, Kuszak AJ, Gumbart JC, Lukacik P, Chang H, Easley NC, Lithgow T, Buchanan SK (2013) Structural insight into the biogenesis of $\beta$-barrel membrane proteins. Nature 501:385. https:// doi.org/10.1038/nature12521

Olsen JV, Ong S-E, Mann M (2004) Trypsin cleaves exclusively c-terminal to arginine and lysine residues. Mol Cell Proteomics 3(6):608-614. https://doi.org/10.1074/mcp.T400003-MCP200

Opuni KF, Al-Majdoub M, Yefremova Y, El-Kased RF, Koy C, Glocker MO (2018) Mass spectrometric epitope mapping. Mass Spectrom Rev 37(2):229-241. https://doi.org/10.1002/mas.21516

Özkanca R, Flint KP (2002) The effect of starvation stress on the porin protein expression of Escherichia coli in lake water. Lett Appl Microbiol 35(6):533-537. https://doi.org/10.1046/j.1472-765X. 2002.01230.x

Parker CE, Tomer KB (2002) MALDI/MS-based epitope mapping of antigens bound to immobilized antibodies. Mol Biotechnol 20(1):49-62. https://doi.org/10.1385/MB:20:1:049

Rinaldi F, Lupu L, Rusche H, Kukačka Z, Tengattini S, Bernardini R, Piubelli L, Bavaro T, Maeser S, Pollegioni L, Calleri E, Przybylski M, Temporini C (2019) Epitope and affinity determination of recombinant Mycobacterium tuberculosis Ag85B antigen towards anti-Ag85 antibodies using proteolytic affinity-mass spectrometry and biosensor analysis. Anal Bioanal Chem 411(2):439-448. https://doi.org/10.1007/s00216-018-1466-z

Rollauer SE, Sooreshjani MA, Noinaj N, Buchanan SK (2015) Outer membrane protein biogenesis in Gram-negative bacteria. Philos Trans R Soc B Biol Sci 370(1679):20150023. https://doi.org/10. 1098/rstb.2015.0023

Sleator RD, Hill C (2002) Bacterial osmoadaptation: the role of osmolytes in bacterial stress and virulence. FEMS Microbiol Rev 26(1):49-71. https://doi.org/10.1111/j.1574-6976.2002.tb00598.x

Storek KM, Auerbach MR, Shi H, Garcia NK, Sun D, Nickerson NN, Vij R, Lin Z, Chiang N, Schneider K, Wecksler AT, Skippington E, Nakamura G, Seshasayee D, Koerber JT, Payandeh J, Smith PA, 
Rutherford ST (2018) Monoclonal antibody targeting the $\beta$-barrel assembly machine of Escherichia coli is bactericidal. PNAS 115(14):3692-3697. https://doi.org/10.1073/pnas.1800043115

Thomas AD, Booth IR (1992) The regulation of expression of the porin gene ompC by acid pH. Microbiology 138(9):1829-1835. https:// doi.org/10.1099/00221287-138-9-1829

Tokarskyy O, Marshall DL (2008) Immunosensors for rapid detection of Escherichia coli O157:H7 - perspectives for use in the meat processing industry. Food Microbiol 25(1):1-12. https://doi.org/ 10.1016/j.fm.2007.07.005

Valderrama WB, Dudley EG, Doores S, Cutter CN (2016) Commercially available rapid methods for detection of selected food-borne pathogens. Crit Rev Food Sci Nutr 56(9):1519-1531. https://doi. org/10.1080/10408398.2013.775567

Wang W, Liu D, Gao Y, Sang Y, Liang X, Liu J, Shi J, Guo L, Pan S (2020) Identification of twelve Aeromonas spp. species with monoclonal antibody-based immunoassay in water and fish samples.
Aquaculture 516:734646. https://doi.org/10.1016/j.aquaculture. 2019.734646

Wang W, Sang Y, Liu J, Liang X, Guo S, Liu L, Yuan Q, Xing C, Pan S, Wang L (2021) Identification of novel monoclonal antibodies targeting the outer membrane protein $\mathrm{C}$ and lipopolysaccharides for Escherichia coli O157: H7 detection. J Appl Microbiol 130(4):1245-1258. https://doi.org/10.1111/jam.14849

Zhao C, Trudeau B, Xie H, Prostko J, Fishpaugh J, Ramsay C (2014) Epitope mapping and targeted quantitation of the cardiac biomarker troponin by SID-MRM mass spectrometry. Proteomics 14(11):1311-1321. https://doi.org/10.1002/pmic.201300150

Publisher's note Springer Nature remains neutral with regard to jurisdictional claims in published maps and institutional affiliations. 